\title{
BUDAPEST LEGFONTOSABB VÁROSMORFOLÓGIAI VÁLTOZÁSAI (1867-1918) A SZABÁLYOZÁSOKON ÉS ESETTANULMÁNYOKON KERESZTÜL ${ }^{1}$
}

\author{
LOVRA ÉVA \\ $\mathrm{PhD}$ egyetemi adjunktus. Debreceni Egyetem Müszaki Kar, Építőmérnöki Tanszék, \\ 4028 Debrecen, Ótemető utca 2-4. E-mail: lovra.eva@eng.unideb.hu
}

\begin{abstract}
Budapest városmorfológiai változásainak hátterében nemcsak a szabályozási rendeletek egy-egy megvalósított intézkedése áll, hanem azok a szakemberek is, akik aktívan részt vettek a városszabályozási diskurzusban. Budapest várostervezési, szabályozási rétegei nem értelmezhetők csupán a városmorfológiai elemzések, az aktuális és városrészspecifikus szabályozások által. Az 1872 és 1896 (1894), valamint 1896 (1894) és 1914 között lejátszódó városfejlesztési folyamatok megfelelő értelmezéséhez ismernünk kell a városfejlődés rétegeit, valamint a döntések mögött álló elveket és gyakorlati feladatokat. A tanulmány összefoglalja a városegyesítés utáni időszak tervezési és szabályozási sajátosságait, különös tekintettel a századforduló időszakára. A bemutatott esettanulmányok a szabályozás és tervezés egy-egy aspektusára koncentrálnak a folyamat ismertetése mellett. A pesti belvárosi és a budai oldalon található esettanulmány-területek vizsgálata kitér a területre vonatkozó szabályrendeletek, várostervek, pályázati anyagok, írott és rajzolt dokumentumok áttekintésére; a városmorfológiai változások elemzésére; a korabeli tervezéselméleti elvek megfeleltetésére és hozzárendelésére, valamint a területre vonatkozó fôbb szabályozás áttekintésére.
\end{abstract}

Kulcsszavak: Budapest, városmorfológia, szabályozások, 1867-1918, városrendezés

\section{BEVEZETŐ - SZABÁLYOZÁSOK ÉS A VÁLTOZÁS IGÉNYE}

A progresszív, államilag támogatott és szabályozott városfejlesztésben az 1872/73ban egyesített Budapest a történelmi Magyarország székesfővárosaként főszerepet játszott. Szerkezetének átalakítása, beépített területének kibővítése a robbanásszerü növekedés miatt felmerülő müködésbeli problémák megoldását irányozta elő a közlekedés hatékonyságának növelésével és a milliós lélekszámúra nőtt város közegészségügyi szempontok szerinti tervezésével és szabályozásával. A törekvések másik mozgatója az volt, hogy „,érszervezésében és építészeti részleteiben egyaránt méltó legyen új, szimbolikus jelentőségéhez" (Moravánszky 1998. 31). A nagyobb hangsúlyt kapott városkép reprezentatív fejlesztésének egyik látványos eszköze - az új utak, középületek mellett - a parkok és kertek létesítése volt, amely nem csupán a mindennapi élet részévé vált, hanem a zöldterületeken elhelyezett szobrok és em-

${ }^{1}$ A kutatást a Magyar Állami Eötvös Ösztöndíj támogatta (No. 280683). Készült Lovra É.: Budapest városmorfológiai változásai és a változások hatásai 1867 és 1920 között. In: Budapest városrendezési (épitési) szabályozásának változásai. Szerk.: Nagy Béla. Mühely Tervező és Tanácsadó Zrt., Budapest 2019. 1-66. o. címü tanulmány felhasználásával. 
lékmüvek által a nemzeti és a polgári öntudat reprezentációjává is. Magyarország fejlődése egyet jelentett a székesfőváros fejlődésével, amely népességszámának rohamos növekedése mellett területének folyamatos bövülésében, szerkezetének funkcionális és reprezentációs átalakulásában is megmutatkozott. Az egyesítést követő évtizedekben kevés olyan év akadt, amelyben a parlament nem tárgyalt volna valamilyen jelentős beruházásra, szabályozásra irányuló tevékenységet, vagy ezeket törvényi és szabályozási szintre ne hozta volna. A léptékváltás nemcsak a városszerkezet szintjén figyelhető meg, hanem a városi tömbök és a városi szövet szintjén is, amelyek mögött a szabályozási rendeletek, felelös tervezési döntések mellett az aktuális új igények is álltak.

A hatékony városszabályozás és városrendezés felételeit csak az 1870-es évek elején tudták biztosítani, a városegyesítés és a Fővárosi Közmunkák Tanácsa (FKT) létrehozása mellett alapvető feltételként szerepelt a megfelelő törvényi háttér megléte: az építtetők adómentességét biztosító törvény (1868: XXII. tc.), a Buda és Pest városok területén végrehajtható ingatlankisajátításról szóló törvény (1868: LVI. tc.), a Pest halasztást nem türő középítkezéseire felvehető kölcsönről szóló törvény (1868: LVII. tc.). A fővárostól függetlenül müködő FKT - amely a Fővárosi Pénzalapot (1870: X. tc.) is kezelte - feladatai közé tartozott az egész fóvárosra vagy egyes városrészekre kiterjedő szabályozási munkák, tervek előkészítése, a tervekre vonatkozó pályázati programok kidolgozása, munkák végrehajtása. Az egyik legfontosabb pedig az építési ügyet szabályozó javaslat (városszabályozás) kidolgozása volt, amelynek kiegészítéseként szabályozási tervek is készültek - az FKT által elfogadott tervek jogerősek voltak, s ezeket kellett betartani a végleges szabályozási terv elfogadásáig, amelynek elkészítése nem feltétlenül követte a várost szabályozó javaslatok elkészítését.

1801-ben azonban a városszabályozási terv (1805) megelőzte a tényleges „,szabályozási rendelkezéseket”2 - a Szépítési Tervet (1808) -, ugyanis József nádor javaslatot tett Pest rendezésére, amelynek első lépése egy városszabályozási terv készítése volt. 1808-ban elkészítette a tíz évre szóló Szépítési Tervet. Míg Hild János építőmester 1805-ös tervében a város fejlődését északra, a mai Újpest felé irányította, addig az 1870-ben alakult FKT a város fejlődését délre, Csepel-sziget irányába terelte. A Szépítő Bizottmány munkájának s a Hild-féle tervjavaslatnak egyes pontjai meghatározzák a város képét, s közvetetten hatottak az FKT munkájára: „Ahol régente a város kapui állottak, ott egy-egy hatalmas teret tervezett [Hild János]; ezek a terek lettek volna a sürün beépített Belváros kopoltyúi. Ahol a Vácikapu állott: ott

\footnotetext{
${ }^{2}$ Nem nevezhető még szabályzatnak, inkább iránymutatás volt ez. A nádor egy építési szabályzatot is készített 1827-ben (Közönséges Építési Rendszabás), de ezt nem alkalmazták. 1839-re készült el a „Közönséges építési rendszabás szabad királyi Pest városára nézve" a hozzátartozó szabályozási térképpel (Pestnek rajz-terve 1838dik Vizáradat következésében munkába vett Rendezésével eggyütt, hivatalos kutfők után ki adatott köz költségen A' viz áradat által szerencsétlenültek Javokra), valamint a Különös Építési Rendszabás Pest Külvárosainak szélső részeire.” A szabályozási rendeletekhez a későbbiekben kiegészítő térképek járultak, amelyekben többek között a város övezeti beosztását tüntették fel - ezek a kiegészítő térképek (a rendeletek vizuális segédletei) nem egyeznek meg a városszabályozási és bővítési tervekkel, amelyek konkrét tervezési iránymutatást adtak. Ezek a tervek vonatkozhattak a teljes városra (ennek hiányát róják fel a 19. és 20. század fordulóján alkotó mérnökök) vagy egy-egy konkrét tervezési területre (Eskü tér).
} 
támadt a Teátrum-piac (Gizella tér, ma Vörösmarty tér]; ahol a Kecskeméti kapu állott, ott támadt a Széna-piac (Kálvin tér). Szinte érthetetlen, hogy a Hatvani-kapunál (ott, ahol a Kossuth Lajos utca találkozik a Rákóczi úttal) nem csinált teret, pedig hely volt bőven és bizonyos, hogy a Nemzeti Színház környéke másképpen festene ma, ha teret rajzol a Hatvani-kapu köré.” (Pásztor 1909. 382-391.)³ A belváros és terei szabályozásának kérdése a Közmunkatanácsot is foglalkoztatta, s a Nemzeti Színház környéke (a mai Blaha Lujza tér) az egyesített főváros egyik városszabályozási feladata volt még a 20. század elején is.

Budapest városmorfológiai változásainak hátterében nemcsak a szabályozási rendeletek egy-egy megvalósított intézkedése áll ${ }^{4}$, hanem azok a szakemberek és alkotók is, akik aktívan részt vettek a városszabályozási diskurzusban ${ }^{5}$. Városszabályozási kérdésekben főként Palóczi Antal nézetei dominálnak, a szakemberek által meghonosított elvek, kritikáik és javaslatok lecsapódtak a városszerkezet és -szövet kialakításában.

Az 1894. évi építésügyi szabályzat ${ }^{6}$ hatályba lépésének évében a Magyar Mérnökés Építész-Egylet sürgette az új szabályozási terv készítésére vonatkozó pályázat kiírását. Mondván, hogy az 1870 . évi X. törvénycikkely meghagyása után a szabályzatot csak 1894. január 1-től léptették életbe. Az 1871-ben kiírt pályázat ideje alatt a város (Pest és Buda) nem rendelkezett pontos területi felmérésekkel, amelyek indokolták volna a tervek megvalósításának lehetőségét, valamint a ,,jelenlegi viszonyoknak már nem felel meg"7. Az 1914-ben kiadott építésügyi szabályzat ${ }^{8}$, amelynek föbb intézkedései az első világháború kitörése miatt nem valósulhattak meg, az 1894. évi szabályzattal összehasonlítva jobban megfelelt a modern városrendezés elveinek.

${ }^{3}$ Megjegyzés: Hild tervében a belváros és a belső körút esetében követte a területfelszabadítás adta lehetőségeket; a terek adottak voltak a lebontott kapuk által felszabadult területen, s nem a tudatos szabályozás, illetve Hild János tervjavaslatának eredményei.

${ }^{4}$ Legfontosabbak (a teljesség igénye nélkül): 1870. évi X. tc. 22.§. (Az építési ügyet a fővárosban szabályozó utasítás); 1871. évi XLII. tc. (körutas-sugárutas rendszer); 1872. és 1874. (Budapest általános szabályozásának és beosztásának tervezete; 1881. évi XLI. tc. (telkek szabályozása); 1884. évi XVII. tc. (Nagykörút építéséhez szükséges jogszabály); 1893. évi XIV. tc. (belvárosi plébániatemplom „,bontása” - nem konkrétan kimondva, az Erzsébet hídra vezető foútvonal kiépítése - a templom megmaradt, de a Lechner Lajos, Heuffel Adolf és Devecis del Vecchio Ferenc tervei alapján megvalósult terv a korabeli Pest belvárosa központjának egy részét megsemmisítette); 1894. (új építésügyi szabályzat); 1894. évi XX. tc. (Lipótváros északi részének rendszerezése, Újépület); 1908. évi XVIII. tc. (a mai Árpád híd helyén Duna-híd megépítése, hídfőkk szabályozása, Erzsébetvároson át vezetendő új fơútvonal nyitása); 1908. évi XLVIII. tc. (a budai Attila út szélesítése és szabályozása); 1914. új építésügyi szabályzat, amely már nyolc építési övezetet határoz meg.

${ }^{5}$ A szabályzatok, rendezési és építési javaslatok kidolgozásában az illetékes Közmunka és Közlekedésügyi Minisztérium (1889-től), a Kereskedelmi Minisztérium, a Fővárosi Közmunkák Tanácsa és meghívásos alapon a Magyar Mérnök- és Építész-Egylet képviselői vettek részt.

${ }^{6} \mathrm{Az}$ 1894-es szabályzat előfutára a Közmunkatanács által hozott utasítás 1886-ban. Mindkét rendelkezés négy övezetre osztja a várost a beépítés típusának szempontjából: egy belső és egy külső zártsorú övezet, egy nyaralóterületnek nevezett, már szabadon álló beépítésü övezet és egy vegyes beépítésű övezet. A Fővárosi Közmunkák Tanácsa így utal a szabályzatra: „1870. évi X. t. cz. alapján alkotott s 1894. január hó 1-jén életbe lépett építésügyi szabályzatunk."

${ }^{7}$ Magyar Ipar 15 (1894. 07. 31.) 7. 157.

${ }^{8}$ ÉSZ 1914 (OSZK TM 973). 
Nyolc építési övezetet határozott meg a városrészek adottságainak megfelelő beépítési feltételekkel, s meghatározta az építkezés alapfeltételét, amely a közművesített terület; a szabályzat kitért az épületmagasságok csökkentésének lehetöségére; a keretes építési mód alkalmazási lehetöségeinek növelésére; növelte az udvarterületeket is és a szabadon álló beépítésü övezetekben az épületek közötti távolságot. A Palóczi Antal $^{9}$ és kortársai által már a 19. század utolsó évtizedeiben hangoztatott várostervezési elvek, amelyek a funkcionalitás és a közegészségügy kívánalmai mellett a terek mủvészi alapokon ${ }^{10}$ való kiképzésére, a változatos beépítésmódra helyezték a hangsúlyt, az 1914-es építésügyi szabályzatban találtak befogadásra.

A városszerkezet, valamint a városi tömbök kialakítása szempontjából jelentős szerep jut a forgalomnak, illetve a növekvő forgalom igényeit kielégítő úthálózat kialakításának, amelyek új utak nyitását, a meglévők szélesítését és szabályozását is jelentették. Az úthálózat racionalizálására vonatkozó tervek a tömbstruktúrák arányainak változását is maguk után vonták. Az 1894-es szabályozási tervben ennek kialakítása nem a korai modern városszabályozási elveket követi, új utcáinak szigorú geometriájú raszterhálója nem veszi figyelembe a terület morfológiáját. „Ennek ellenében a mai városépítészet azt tanítja, hogy az úthálózat kiképzésben jellegzetességre kell törekedni, a városi területet nem szabad sakktáblának rastrir-mezőnek nézni, hanem megkülönböztetendők a város különbözö területrészei fekvés és sajátosságra nézve, különbség teendő a sík és lejtős vidékek között, és a beépítés különböző módjaihoz képest, a lakosság soknemủ igényei szerint változatossággal és mủvészettel

\footnotetext{
${ }^{9}$ Palóczi Antal volt korának egyik legtermékenyebb várostervező teoretikusa, aki ugyan foglalkozott gyakorlati tervezéssel is, azonban jelentősége inkább elméleti munkáiban, a szabályozásokra és várostervezési elvek kialakítására gyakorolt hatásában van. A jelen tanulmányban nem célzottan jelenik meg ennyiszer Palóczi, hanem tevékenysége miatt, amely kiemelkedik a kortársak várostervezés-elméleti munkái közül, akik gyakran idézték is őt (lásd: Mudrony Soma: Budapest jövöje. Országos Iparegyesület, Budapest 1893). A Palóczi Antal munkásságával jelenleg is foglalkozó kutatások eredményei a közeljövőben kerülnek publikálásra.

${ }^{10} \mathrm{~A} 19$. század vége várostervezési mozgalmának, az esztétikai tervezésnek (Camillo Sitte, 1889) térnyerése a „mérnöki” szemléletet visszaszorította, azonban ez nem azt jelentette, hogy a várostervezök nem vették figyelembe a terület morfológiáját és a felmérések eredményeit, sőt. A természeti formák figyelembevétele vezetett a (magyar) városok felmérésének tökéletesítéséhez is. Palóczi és kortársai hangsúlyozták, hogy megfelelő alaptérkép nélkül nincs pontos városterv, s a kataszteri felmérések erre alkalmatlanok. - Szesztay László, műegyetemi magántanár $A$ városmérés rendszere és szabályai című összefoglaló munkáját 1902-ben, a II. magyar országos technikus kongresszuson mutatta be. A munka mind elméletben, mind gyakorlatban foglalkozott a városok felmérésével és a bővítési tervek elkészítésével. Szorgalmazta a városméréseknél a méterrendszer bevezetését az addig követett ölrendszer helyett. A kongresszus Szesztay ajánlatára határozatot hozott a hazai városmérésekre vonatkozóan, kötelezővé tették a legkisebb négyzetek módszere szerint való kiegyenlítés alkalmazását a közcélú trigonometrikus munkálatoknál, valamint a méter rendszer használatát. E cél elérése érdekében a kongresszus a Magyar Mérnök- és Építész-Egyletet kérte fel, hogy városmérésre vonatkozó múszaki szabályzatot készítsen, amely a korabeli Magyarország városainak felméréseinél útmutatójaként szolgál. Szesztay az 1909. évi magyar városok országos kongresszusán tartott előadásaiban hangsúlyozza a városszabályozás alapját képező városmérés fontosságát és nélkülözhetetlen voltát, s tevékenysége megteremtette a korszerü városszabályozás és városbővítés alapjait. - Így, a szakirodalomban szorgalmazott mérnöki és esztétikai tervezés helyett helytállóbb lenne arra utalni, hogy az esztétikai figyelembe vette a természeti viszonyokat, a mérnöki vonal pedig a vonalzós tervezés híve volt. (Lásd: MoravčíkováLovra-Pastoreková 2017. 30-43.)
} 
szükséges kialkotni az úthálózatot!" ${ }^{11}$ A beépítés szempontjából a négy építési övezet nem ad kellő flexibilitást. Az I., II. és IV. övezetben zártsorú beépítést javasol, növelve a már magas beépítési sürüséget, amely a közegészségügyi szempontokat is figyelembe véve nem a legmegfelelőbb megoldás. Az 1894-es szabályozás nem javasol tágas tereket, a megállapított utcaszélesség és épületmagasság aránya is kedvezőtlen, és az esztétikai követelményeknek eleget tenni pedig lehetetlen az utcák raszterhálója miatt (változatos terek, perspektivikus határok hiánya).

A Fővárosi Közmunkák Tanácsa jelentéseiben rendre úgy utal az 1894-es építésügyi szabályzatra, mint az 1870. évi X. tc. alapján alkotott s 1894. január hó 1-jén életbe lépett építésügyi szabályzatunk. A törvénycikkely alapján alkotott szabályzatot ideiglenes utasításként fogadták el, s főbb rendelkezései 1894-ben legitimáltattak. 1870 második felében tárgyalták, s megállapították, hogy módosítások, mint a „kötelezettségek szabatosabb körülírása és az eljárás szabályozása okvetlenül szükséges" ${ }^{12}$. A módosítások elveit egy albizottság dolgozta ki, amelynek javaslatait elfogadták, s ,még 1870. October havában, mint ideiglenes utasítás Buda és Pest városok középitészeti bizottmányai számára, az építkezés ügyében Buda és Pest városok közönségeivel közöltetett is"'13. A négy szakaszból álló ideiglenes utasítás első része a hatósági bírálat alá bocsátandó építkezési tervek készítéséről, a második az utcák lejtszinti magasságáról, a földszinti padozatról, a kapuküszöb magasságáról, a járda-, a lépcsők- és a földalatti helyiségekről, valamint a régi épületek lényeges átalakításáról szól. A harmadik szakaszban a kiszögellésekről, lábazatokról és az utolsóban a házak magasságáról és a járdákról értekeznek. „Ez ideiglenes utasítás azonnal életbe is léptettetett s úgy a középitési bizottságok és városi tanács, mint a közmunkák tanácsa részéről minden előforduló ügyek megbirálásánál vezérfonalul szolgál"14.

Már a 20. század első évtizedének végén megfogalmazódnak olyan kritikai észrevételek (ezek folyamatosak a városfejlődés során), amelyek Budapest szabályozási tervének megújítását szorgalmazzák, $\mathrm{s}$ esetlegesen városrendezési pályázat kiírását is kilátásba helyezik. 1908-ban a berlini városépítő kiállításon Budapest is szerepelt, s ezzel párhuzamosan egyre konkrétabb javaslatokkal léptek fel az új szabályozások, illetve egy új városszabályozási pályázat kiírásának érdekében.

Mindeközben már folyt az 1894-es építésügyi szabályzat revíziója, amelynek bizottságát 1904-ben állították össze. A bizottság, amely az 1894-es városszabályozás, illetve ennek megelőző szabályozási rendeleteinek felülvizsgálatát is végezte, munkájába bevonták nemcsak a szakhatóságot, hanem azokat a társadalmi szakköröket, amelyek az építés ügyével hivatásszerüen foglalkoztak, így a Fővárosi Közmunkák Tanácsa, a főváros közönsége, a Magyar Mérnök- és Építész-Egylet, a Budapesti építőmesterek, kőműves, kőfaragó és ácsmesterek ipartestülete, a Magyar építőmüvészek szövetsége és a Magyar építőmesterek egyesülete képviseltette magát.

${ }^{11}$ Palóczi Antal: Miért szükséges Budapest szabályozási tervének megújítása. MMÉEK 42 (1908. 04. 05.) 13. 131 .

${ }^{12}$ Ideiglenes építkezési utasítás. In: FKT jelentés $(1870,1871) 20$.

${ }^{13}$ Uo.

${ }^{14}$ Uo. 
A bizottság 1905. február 7-én tartotta első ülését, s a revízió 1913-ig tartott párhuzamosan az új építésügyi törvény összeállításával (1914).

Palóczi Antal részt vett a bizottság munkájában a Magyar Mérnök- és ÉpítészEgylet képviseletében, s a szabályozási terv kialakításának folyamán konstatálta, hogy a terv nem gondoskodik a jövőben építendő középületek megfelelő elhelyezéséről (ekkor még nem tudhatta, hogy a főváros intézményhálózata egy évtized múlva már túlságosan kiterjedt lesz a lakosság számának és az ország területének lecsökkenése miatt), továbbá a pályaudvarok és a város forgalmi eszközeinek elhelyezéséröl sem gondoskodik. A város harmonikus fejlödése érdekében szükségesnek tartja, hogy a város a Duna mindkét partján egyformán terjedjen, és kiküszöböljék a szándékot, hogy a város kiépítése egyedül a rákosi homokrétekre koncentráljon. „Budapest középpontjául kell, hogy a Duna maradjon meg." ${ }^{15}$ Az elképzelés utópisztikus, azonban az 1894-es törvénnyel szemben megfogalmazott kritikái helytállóak, s egyik legjobb példái a szabályozási anomáliáknak az Eskü tér (ma Március 15. tér) és a hídfö környezetének rendezése és tervezése során tapasztalt problémák. Mivel a szabályozási rendelet nem határozta meg a tervezési kereteket, legyen az a beépítés változatossága vagy éppen azok az épületek, amelyek áldozatul eshetnek a modernizációnak, a belvárosi templom kérdése hátráltatta a munkálatokat, valamint övezeti és városszöveti „elcsúszást” eredményezett. A korabeli példák sora folytatható: Erzsébet sugárút, budai körút, új városháza (stb.). Palóczi egy új városszabályozási terv készítését javasolja a 1894-es szabályozás revíziójával, valamint az új építésügyi szabályzat megalkotásával párhuzamosan ${ }^{16}$, s teszi ezt már 1904-től. A 20. század elején hatályos tervet, amelyet a Fővárosi Közmunkák Tanácsa szerkesztett, 1904ben tették közzé. A városszabályozási és részben városbővítési terv kritikájaként Palóczi négy pontban fejtette ki megalapozott véleményét, ezzel is reflektálva a kor népszerű városszabályozási elveire, illetve szabályozási kritériumaira: 1. a forgalom, 2. a beépítés, 3. a közegészségi és 4 . a müvészi, azaz szépségi követelmények.

Az 1908. évi XLVIII. törvénycikk Budapest székesfőváros fejlesztéséről s háztartásának rendezése végett teendő állami intézkedésekről meghatározza a belváros (IV. kerület) és az V. kerület azon részeinek adó- és felújítási-építési kötelezettségeit, amelyek a városszabályozás területére esnek. A belváros szabályozását a Fővárosi Közmunkák Tanácsa tevékenységének keretein belül végezték. A városok szabályozásához való hozzáállás 1912-ben hozott fordulatot. Az 1912. évi LVIII. törvénycikk indoklása a városok fejlesztéséről kimondja, hogy az 1886. XXI. és XXII. törvénycikkek, amelyek eddig a városok helyzetét szabályozták, elavultak. A 12-13. § foglalkozik a közintézményekkel, amelyeknek három csoportját határozza meg: a feltétlen létszükséglet, a már fejlettebb városi együttjáró és a kényelmi igények kielégítésére szolgáló intézmények, melyek kialakítása is ezt a sorrendet kell, hogy kövesse, azonban: „A közintézmények nem a természetes szükségszerüség és előre átgondolt szerves program, hanem pillanatnyi tényezők hatása szerint jöttek létre.” Ezen a gyakor-

${ }^{15}$ Épitö Ipar 32 (1908. 03. 8.) 10. 104.

${ }^{16}$ Palóczi Antal: Miért szükséges Budapest szabályozási tervének megújitása. MMÉEK 42 (1908. 04. 5.) 13. $129-133$. 
laton is változtatni kíván. A tervezettség a törvény által visszanyúlt az alapokhoz, s olyan már-már evidensnek számító témákat vett elő, mint a közegészségügy és annak intézményrendszere. A városok szabályozásának rendszere, illetve a háttere egy kevésbé monumentális intézkedéseket szorgalmazó, inkább realista időszakába lépett.

Az 1912-es törvény a városfejlesztésről már elöirányozza, illetve megteremti a hátterét annak a budapesti építésügyi szabályzatnak (1914), amely lényegében átformálja és meghatározza a föváros beépítési lehetőségeit. A tervezetet a Közmunkatanács 1913. októbertől 1914. januárig véglegesítette, majd 1914. január 27-én tartott ülésén az 502. sz. alatt kelt határozatával állapította meg az új építésügyi szabályzatot, amely 1914. március 1-töl lépett életbe.

Az új szabályzat ${ }^{17}$ a város területét nyolc (plusz egy - zöldterületek) övezetbe osztja be:

I. zártsorú építkezéssel a telek utcai vonalán, ahol a legnagyobb épületmagasság 25 méter legalább 15 méter széles utcában, s 15-25\%-os udvar javasolt;

II. zártsorú építkezéssel az utcai vonalon, a legnagyobb épületmagasság 25 méter legalább 18 méter széles utcában, 17-25\%-os udvar;

III. szabadon álló építkezéssel, legalább 300 [négyzet]öles telken és legfeljebb 34\%-os beépítéssel, a legnagyobb épületmagasság 14 méter a legalább 11 méteres utcában, s a szabadon hagyandó terület legalább $66 \%$;

IV. szabadon álló építkezéssel, legalább 600 [négyzet]öles telken, legfeljebb 20\%-os beépítéssel, ahol a legnagyobb épületmagasság 11 méter, a szabadon hagyandó terület legalább $80 \%$;

V. zártsorú építéssel az utcai vonalon, legnagyobb épületmagasság 21 méter legalább 18 méter széles utcában 24-35\%-os udvarterülettel;

VI. szabadon álló építkezés legfeljebb 50\%-os beépítéssel, legnagyobb házmagasság 17 méter legalább 15 méteres utcában és a szabadon hagyandó terület legalább $50 \%$;

VII. zártsorú beépítés, 5,69 méteres (3 öles) elökerttel, 600 [négyzet]öl telekminimummal és legfeljebb 45\%-os beépítéssel, legnagyobb épületmagasság 17 méter legalább 18 méter széles utcában, a telken szabadon hagyandó terület legalább 55\%;

VIII. szabadon álló építkezés, legfeljebb 45\%-os beépítéssel, legnagyobb házmagasság 14 méter, legalább 15 méter széles utcában; szabadon hagyandó terület legalább 55\%.

Az 1914-es szabályozás kísérletet tett az övezetek határterületei különböző beépítési léptékének harmonikus áthidalására, valamint az 1912-es törvény intézményhálózat ésszerüsítésére - mondhatni, hogy a budapesti rendelkezések a közelgő első világháború árnyékában nőttek fel igazán a főváros jelentőségéhez.

Az új szabályzatban követett rendezési és kiépítési rendszer kiegészítéseként a rendelkezés az övezetek közötti határok (érintkező helyek) beépítési dinamikájának meghatározásáról is rendelkezett, hogy az a „kedvező városkép szempontjából is megnyugtató átmenetet biztosít[son]"18. A harmonikus átmenetet célzó intézkedések

${ }^{17} \mathrm{Az}$ „uj épitésügyi szabályzat”. In: FKT jelentés (1913, 1914, 1915) 35.

${ }^{18}$ I. m. 40. 
mellett a szabályzat különleges építési módokat és területeket is meghatározott (X. fejezet), amelyek ,az övezeti általános tagolás mellett további változatosságot hoznak a városképbe" 19 - az esettanulmányok elemzése során a konkrét területekre vonatkozó rendelkezések is bemutatásra kerülnek.

A városképre vonatkozó általános rendelkezések közül néhányat ki kell emelni, amelyek foganatosításával a főváros képe másként alakult volna: 162. § megtagadható az építési engedély olyan építkezések és homlokzatkiképzés esetén, amelyek rontanák a városkép összhangját, valamint a fontosabb tereken és utcákon emelendő épületek esetén fokozottabb építőmüvészeti követelések támaszthatók.

A város alaktani változásai és a városi szövetek alakítása szempontjából lényeges az a döntés, miszerint: „A városi épitési fejlődésének helyes irányítására a megfelelő eszközt nem a telekméretek, hanem az épitési mód megállapításában találjuk"20. A szabályzat azonban figyelmen kívül hagyott számos olyan tényezőt, amely a város célzott harmonikus fejlődését garantálta volna a Nagy-Budapest már pontosabban kidolgozott ideájának (1914) figyelembevételével.

\section{BELVÁROS - ÖSSZEFÜGGÉSEK}

„Mint mindennek, a mi régi, úgy a belvárosnak szabályozása is, mely minden kívánalmat kielégítsen, kétségkívül igen nehéz, föleg pénzügyi szempontból, s e miatt a létező, bár igen kedvezőtlen állapotra a szabályozási terv megállapításánál különös figyelmet kellett fordítani, úgy annyira, hogy e városrész utczáin csak is a legszükségesebb változtatások lettek tervbe véve." ${ }^{21} 1885^{22}$-töl a belváros tervezett szabályozásának legfontosabb részét a Sebestyén (ma a Ferenciek tere) és a Hatvani (ma Kossuth Lajos) utca kiszélesítése képezte (a főváros a Duna utca ${ }^{23}$ szabályozását jogi problémák miatt elvetette, azonban ehhez az FKT nem járult hozzá - a végső, belügyminisztériumi döntés szerint a Duna utca is kiszélesítendö). A belvárost úgy jellemezték, hogy annak szük utcái minden rendszer nélkül valók, $\mathrm{s}$ a beépítési sürüség miatt az épületek levegő és világosság hiányában vannak. A belső utcahálózat nem kapcsolódik más városrészek közlekedési ereivel. „A belvárost minden oldalról szép, tágas forgalmi utak övezik, de ezekből nem vezetnek a belvárosba olyanok, melyek akár a forgalom igényeit kielégítenék, akár alkalmasak volnának arra, hogy rajtuk a levegő dúsan beömöljék; s noha a belváros a Duna mellett nyúlik el, abban a légáramlat annyira megakad, mikép nincs városrész, mely ezen szempontból oly szerencsétlen helyzetben volna, mint épen a belváros, mely a pesti résznek most is

${ }^{19}$ I. m. 41.

${ }^{20}$ I. m. 42 .

${ }^{21}$ I. Szabályozás. In: FKT jelentés (1885) 9.

${ }^{22} 1885$ irányadó dátum, mert miközben a fơváros a belváros rendezésével küzd, aközben az 1884. évi XVII. tc. lehetővé teszi a Nagykörút egységes és hatékony fejlesztését - paradoxon, hogy a Duna utca szabályozását egy kisajátítási ügy miatt fogta vissza a főváros, míg a Nagykörút kialakításának egyik alapfeltétele a kisajátítások voltak.

${ }^{23} \mathrm{Az}$ egykori Duna utca helyén ma a Március 15. tér és a kapcsolódó Duna utca egy rövid szakasza van. 
zömét képezi." ${ }^{24}$ A Közmunkatanács korabeli megállapítása azért (is) jelentős, mert ezek azok a körülmények, amelyek a szabályozási tervezet feladatainak meghatározásánál a legnagyobb szerepet játszottak: a meglévő utcák szabályozása, szélesítése, hogy alkalmassá váljanak a forgalom igényeinek kielégítésére, az utcák összekötése a többi városrész útjaival (lehetőleg az egyenes kapcsolat megvalósítása); a közegészségügy szempontjai miatt pedig a szabályozással friss (dunai) levegőt akartak juttatni az épületek közé - a Duna, a Sebestyén és a Hatvani (a mai Kossuth Lajos) utca szerepét is ebben látták: a belváros összekötése a belső körúttal és a Kerepesi (a mai Rákóczi) úttal.

A belváros egységes szabályozását a terenként és utcánként kialakított szabályozási megoldások, gyakran változó rendeletek előzték meg, meghatározták az utcák szélességét, a terek méreteit és az egyéni kisajátítások mértékét, amely által a bővítések megvalósulhattak. Az egységes, a belváros teljes képét érintő hivatalos szabályozási terv készítése még váratott magára. A kisebb rendezési munkák után a belváros szabályozása mint jelenség egyet jelentett az Eskü tér (ma Március 15. tér) és a híd pesti hídföjének kialakításával, amelyet megalapozott az 1893. XII. törvénycikk, amely a két híd építésének és a belváros átalakulásának kezdetét jelentette. Az évek során számos térrendezési javaslatot tettek, a vezető irányelvek figyelembevételével, a tervekhez pontos számításokat, építészeti és városépítészeti megoldásokat mellékelve ${ }^{25}$.

Palóczi Antal egységes belvárost szabályozó terve ${ }^{26}$ (1892) megelőzte a 1893. évi rendeletet, amelyben kijelölik az új Duna-hidak helyét. Palóczi tervében a Károly laktanya telkét felosztotta és kulturális intézmények épületeinek helyeként, valamint közparkként alkotott új városszerkezeti elemet. Az új városháza az Eskü tér hídja mellett helyezkedik el, feltünő a Belváros jobb oldalának szabályozása - új utakat nyitott, amellyel a közlekedés racionalizálása mellett lazította a sűrủ tömbszerkezetet, szabályosabb városi tömböket alakított ki.

Szerdahelyi Ágost városi mérnök javaslatának és a szabályozások menetének ismertetésére ${ }^{27}$ a Palóczi Antal által felvetett gondolatok és tervjavaslat bemutatása után került sor, mintegy reflektálni akarván a rendezési ötletekre. Szerdahelyi két tengelyt vett fel az Üllői út és a Váci körút - a mai Bajcsy-Zsilinszky út - vonalában, ezek metszéspontjában vette fel a harmadik tengelyt, ami a mai Rákóczi út meghoszszabbítása, s keresztülvezet a helyspecifikus szabályozási rendeletek által kiszélesítendőnek ítélt Hatvani (mai Kossuth Lajos) utcán. Tervében a híd tengelyvonala megegyezik a harmadik tengelyvonallal, amely átvágja a belvárosi plébániatemplomot. A tengelyvonalak menti szabályozás ötlete Perjátl Mártontól származik ${ }^{28}$.

\footnotetext{
${ }^{24}$ I. Szabályozás. In: FKT jelentés (1885) 9.

${ }^{25} 1895$ áprilisában a tárgyalások egy olyan terv elfogadásával értek véget, amely a plébániatemplom, a régi városháza és a kegyesrendiek épületének lebontását javasolja.

${ }^{26}$ Palóczy Antal: Tervjavaslat a fóváros belvárosának szabályozására. MMÉK 26 (1892) 3. 69-71.

${ }^{27}$ Szerdahelyi Ágost: Budapest belvárosának szabályozása. MMÉK 26 (1892) 3. 72-75.

${ }^{28}$ Épitö Ipar 15 (1891. 12. 23.) 781.
} 
A városi tömbök szabályozásával teljesen átalakul a belső mag - az Eskü tér és környezete -, a városi tömbök dimenziói egységesebbek, szabályosabbak, szélesebb utcákat és tereket valósítanak meg. A tervjavaslatban nem szerepel a Károly laktanya tömbjének ötletterve (1900), csak az új városháza Duna-parti tömbjének (1898) kijelölése a híd és a part találkozásánál - a városháza felett egy vásárcsarnokot vizualizál. Így a Belváros középpontját az új városháza, az Eskü téri híd és az ide irányuló fő közlekedőút alkotná.

A tervjavaslat és a tervdokumentáció szerint több utca nyitását javasolja, így felaprózva a túlméretezett városi tömböket (ezek közül az Egyetem térről a Sándor utca felé irányuló átvágás a szabályozási tervben szerepel, azonban nem valósították meg).

A városi mérnök kilátásba helyezi a szigorú és következetes építésügyi szabályozás összeállítását, amelyre végül csak 1914-ben kerül sor (az ezt megelőző 1894-es szabályozás is kísérletet tesz erre): ,a Belvárosban emelendő monumentális müveknek, ú. m. az új hidaknak, a Városháza új palotájának és egyéb új középületnek létesítését pendítették meg, a hozzá értő szakkörök szigorú tervszerüséggel és szívós kitartással már eleve arra törekedjenek, hogy a majdan kifejlődő és nagy erővel meginduló magánépítkezéseknek jól átgondolt szabályozó tervezettel oly irányt adjanak, hogy az említettük korszakalkotó müveknek méltó környezetét alkothassák"29. Az 1914-es építésügyi szabályzat alapján a pesti oldalon az I. övezetet mint központi magot a II. övezet közvetlen csatlakozással félkörívben, a város egész területén, Dunától Dunáig veszi körül. Az I. övezetre vonatkozó építési szabályok szerint zárt sorban kell építkezni, 14 m házmagasságig szabad minden utcában, a házmagasság és utcaszélesség aránya $\mathrm{s}$ a hozzá kapcsolódó udvar mérete a következőképpen alakult: 17/9 (min. $6 \mathrm{~m}), 21 / 10$ (min. 7,5 m), 25/15 (min. $9 \mathrm{~m})$. A belváros egységességét erősítő rendeletek szerint a tereken, a Duna-parton (vonatkozik a Duna jobb és bal partjára egyaránt) az új épületek magassága legfeljebb 25 méter (129. §.) lehet, a Ferencz József (ma Széchenyi István) téren már fennálló legmagasabb épület föpárkánymagasságát (128. §.) nem haladhatja meg az építendő épület fópárkánymagassága.

\section{ERZSÉBET HÍD PESTI HÍDFŐ - ÚJ KÖZTERÜLETEK, TELJES ÁTÉPÍTÉS}

Az 1893. évi XIV. törvénycikk a fö- és székvárosban két állami Duna-híd építéséről meghatározta a Rudas-fürdő előtti tér és az Eskü téri római katolikus plébánia épülete (ma Belvárosi Nagyboldogasszony Főplébánia-templom) között építendő Duna-híd hídfőinek területét és a kisajátítás mértékét ${ }^{30}$. Az 1893-ban elrendelt kisajátítások ellenére a terv csak 1895-ben készült el, így a kisajátítások során igényelt

\footnotetext{
${ }^{29}$ Szerdahelyi Ágost: Budapest belvárosának szabályozása. MMÉK 26 (1892) 3. 73-75.

${ }^{30}$ A kisajátítási törvény kibővített változatát alkalmazták, amely 1881-ben lépett hatályba (1881. évi XLI. törvénycikk a kisajátításról - ennek, az 1893-as törvényben alkalmazott 25. §-a).
} 
kártalanítási összegek egyre magasabbak lettek ${ }^{31}$, gátolva a munkálatok tényleges, hatékony megvalósulását. A Közmunkatanács évenkénti összefoglalójában kitért az Eskü téri híd szabályozási munkálatainak alakulására, az 1895-ös jelentésében a „II. Dunai uj hidak” fejezet kifejti, hogy a főváros nem fogadta el azt a szabályozási javaslatot, amelyet az 1893-as törvény után állítottak össze. Valamint új szabályozási tervjavaslatot készített, a döntési mechanizmus az 1895. április 9-én 399. kgy. sz. a. hozott tárgyalásokkal ért véget egy olyan terv elfogadásával, amely a plébániatemplom, a régi városháza és a kegyesrendiek épületének lebontása által valósítja meg a szabályozást (1. ábra).

A Közmunkatanács már 1891-ben egy gyalogos híd építését javasolta a templom érintetlenül való hagyása mellett, valamint azon megfontolás szerint dolgozták ki ,az eskütéri híddal kapcsolatos szabályozás tervét, hogy a kerepesi-út [Rákóczi út] egyenes meghosszabbítást nyerjen a Dunáig"32. Az 1891-es éves jelentés nem tartalmaz a tárgyhoz tartozó tervmellékletet, csak javaslatokat. A szabályozási tervezet az 1892. évi jelentésben, az 1891. szeptember 9-én és 15-én tartott tanácskozás jegyzőkönyvében található $^{33}$ (2. ábra). A tanácskozáson elfogadott javaslatok a hidak helyéröl és a szabályozandó területről tekinthetők az 1893. évi XIV. törvénycikk alapjának. A Közmunkatanács 1891-es javaslata szerint a bal parti feljárót a belvárosi templom déli homlokzatával párhuzamosan kell elhelyezni a templomtól 13 méterre, a Duna utca beépítését $\mathrm{s}$ az utca forgalmának átvezetésére a feljáró déli oldala mellett egy 15 méter széles, a Rózsa tértől ${ }^{34}$ a Ferencz József rakpartra vezető új utca nyitását javasolja ${ }^{35}$.

A főváros és a Közmunkák tanácsának javaslata közötti legnagyobb különbség a plébániatemplom helyzete, azaz a pesti hídfö kiképzése. Míg a Közmunkatanács tervében a feljáró már a Zöldfa (a mai Veres Pálné) utca meghosszabbított vonalától támfalak közé fogva nyelv alakban jelenik meg, addig a fóváros tervében térszerüleg nyer kiképzést, s így a híd feljárója nem csak egy irányból közelíthető meg. 1895ben, a két terv elemzésekor és várható kivitelezési költségeinek összehasonlításakor még egyik sem számított véglegesnek, a későbbi várostérképek tanúsága szerint egy harmadik, a két terv egyes pontjait magába foglaló tervet fogadtak el.

A várostervezési elvek hatásának vizsgálata szempontjából a főváros tervének hídfőmegoldását kell figyelembe venni. A hídfő előtti tér kiképzése a Stübben-féle elképzelést követi, miszerint a kiterjedt terület megköveteli annak felosztását és szigetek kialakítását, amely egyrészről a tér egészéről alkotott egységes képet zavarja, másrészről pedig a részletekben rejlő szépséget növeli, ugyanis ezek a szigetek nö-

\footnotetext{
${ }^{31}$ A Fővárosi Közmunkák Tanácsa 1898. évi müködéséről szóló hivatalos jelentésnek ismertetése. I. Épitő Ipar 23 (1899. 10. 26.) 319 és FKT jelentés (1898) 2.

${ }^{32}$ II. Dunai uj hidak. In: FKT jelentés (1895) 24.

${ }^{33}$ VII. Dunai uj hidak. In: FKT jelentés $(1889,1890,1891)$; II. Dunai uj hidak. In: FKT jelentés (1892, 1893, 1894).

${ }^{34} \mathrm{Az}$ egykori Rózsa téren a Klotild palota épülettömbje áll.

${ }^{35}$ VII. Dunai uj hidak. In: FKT jelentés (1889, 1890, 1891); II. Dunai uj hidak. In: FKT jelentés (1892, 1893, 1894).
} 


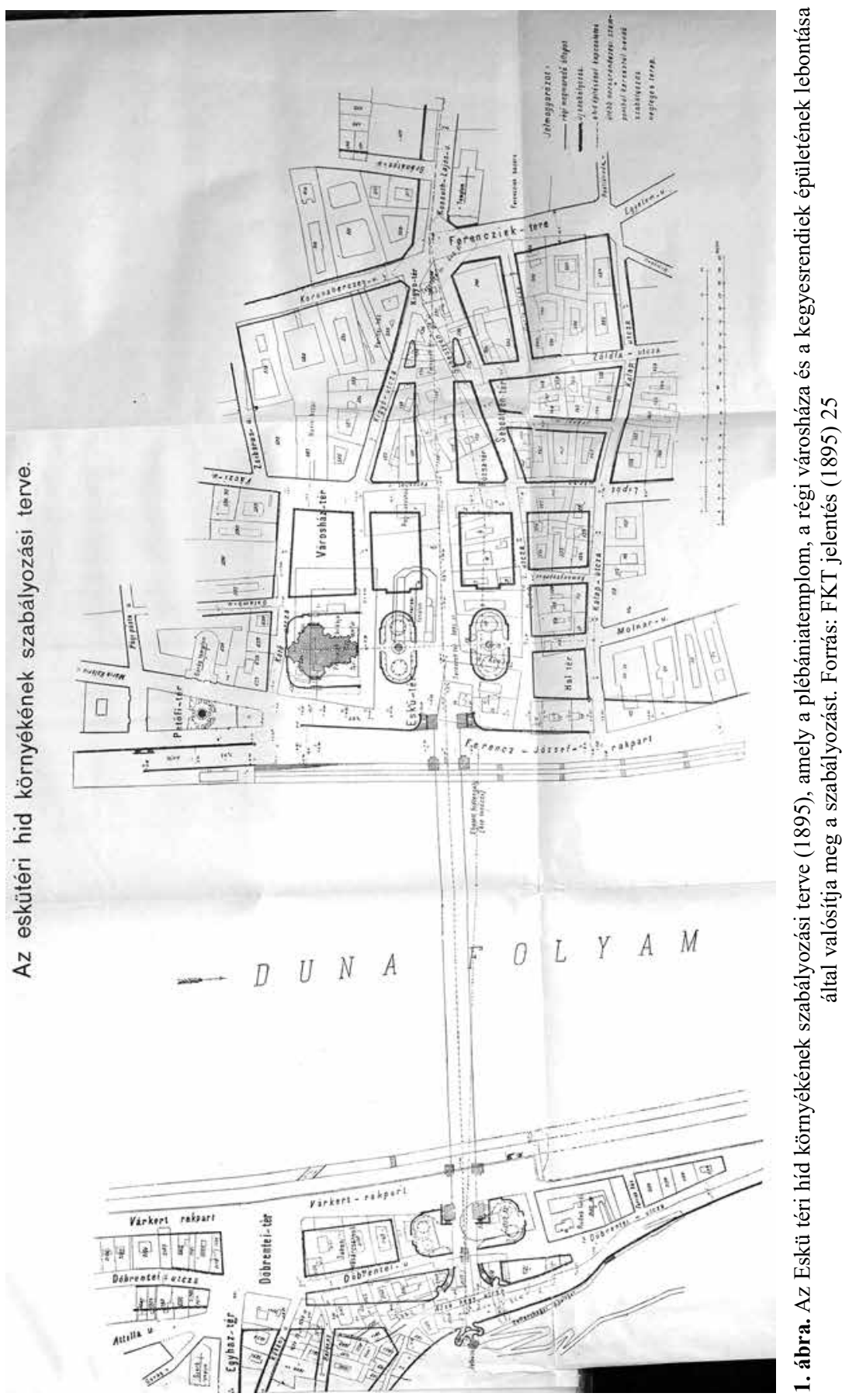




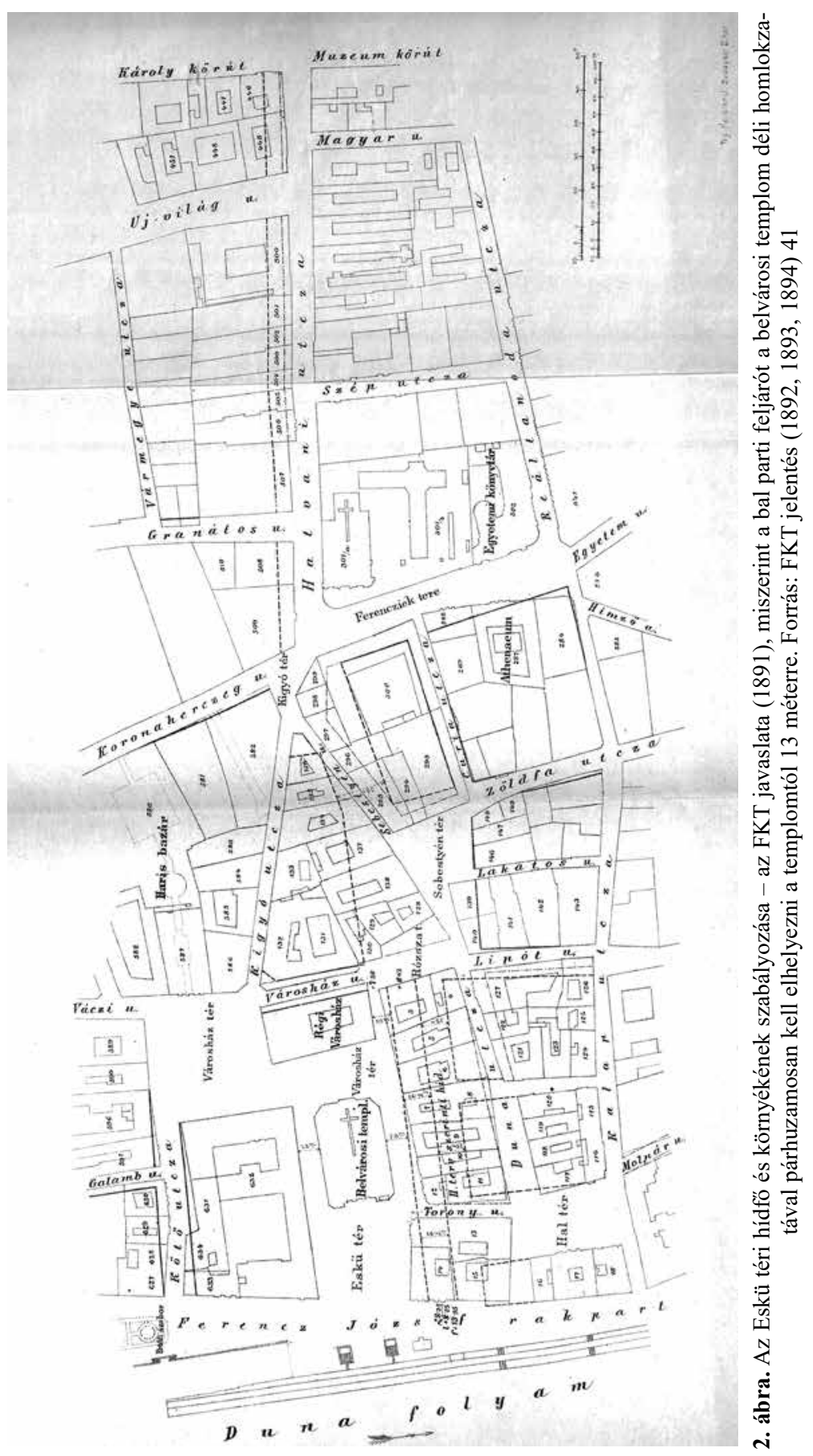




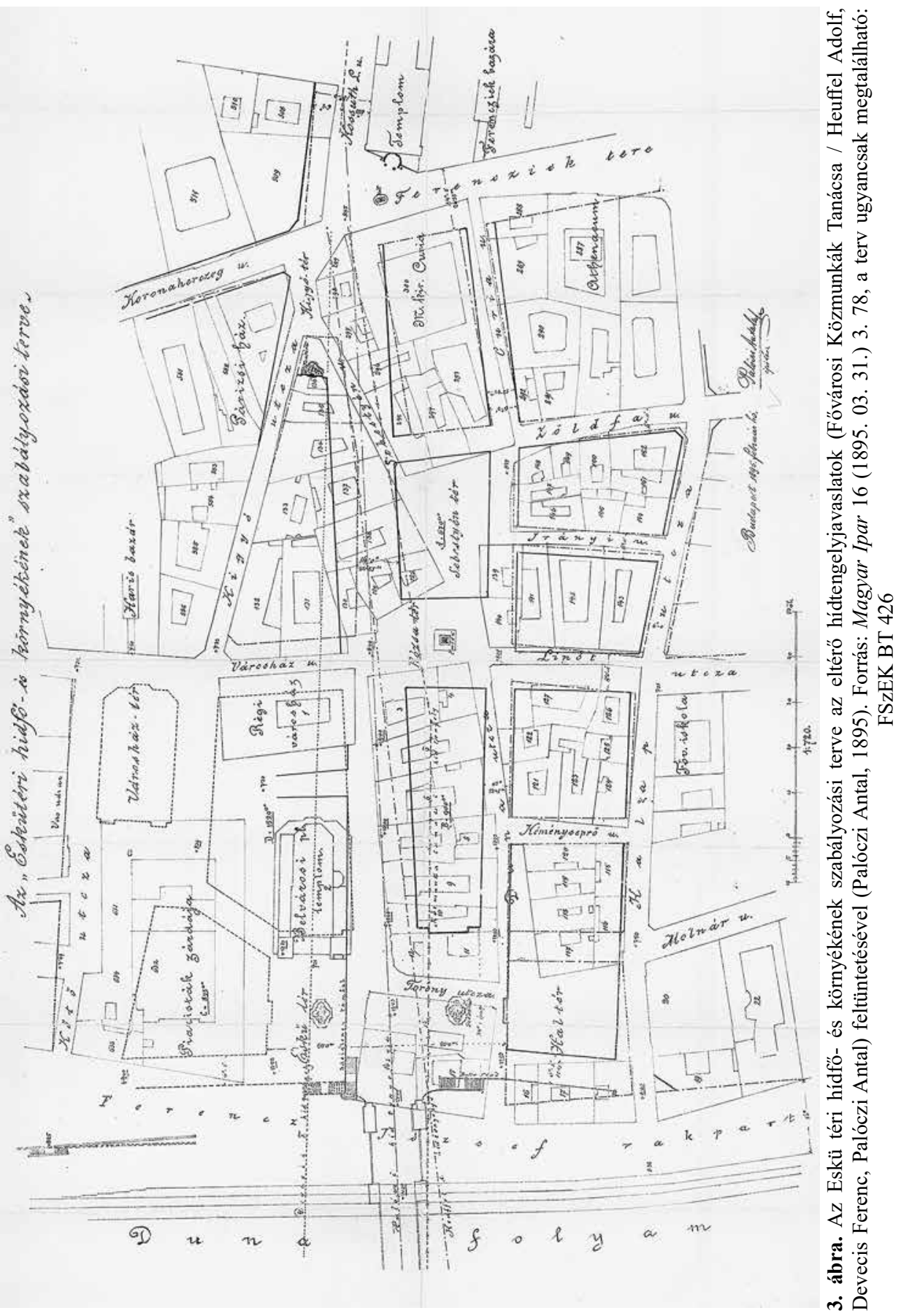


vényzettel, szökőkutakkal, szobrokkal (stb.) ékesíthetők ${ }^{36}$. Stübben meghatározza a hídfő fajtáját is, amelynek leírását Palóczi egy az egyben átveszi töle és megjelenteti müvében: „,b) Az egy tengely irányában symmetrikus [sic] tér: alakja félkör egész a derékszögletes négyszögletig; ott, hol a forgalom egy föirány - egy foépület felé gravitál. Igy pl. városi kapuk, hídfők, vasúti indóházak stb. elött”" ${ }^{\text {"37. }}$

Palóczi Antal 1895-ben egy szabályozási tervjavaslatot ${ }^{38}$ nyújtott be az Eskü téri híd hídföjének és környezetének szabályozása tárgyában az eltérő hídtengelyjavaslatok (Fővárosi Közmunkák Tanácsa / Heuffel Adolf, Devecis Ferenc, Palóczi Antal) feltüntetésével (3. ábra). A szabályozással kapcsolatos felolvasásában kifejti, hogy a Magyar Mérnök- és Építész-Egylet 1894 januárjában vitatta meg a szabályozást, s ekkor amellett foglalt állást, hogy a belvárosi plébániatemplomot nem tartja olyan mủemléknek, amit a megfelelő városszabályozás kockáztatása árán feltétlenül meg kell tartani. A felvázolt Devecis-féle terv szerint a Kossuth Lajos utca meghosszabbításával a híd a belvárosi plébániatemplom északi határvonalát érintve, ferde irányban vágja át a Dunát, így csatlakozva a budai oldalhoz (Döbrentei tér).

Palóczi azonban az esztétikai kívánalmakat figyelembe véve egy meröleges, illetve majdnem merőleges megoldást javasol: „A Duna két partjára egyenlő mértékben majdnem merőlegesen fektetendő hídtengelyt addig csúsztatjuk a Dunán, mig iránya a Kossuth Lajos-utcza tengelyével a Ferencziek-tere körül találkozik. Ez egyszerủ s a fentiek értelmében tekintetbe vett összes föltételeknek megfelelően húzott vonalzással azt a hid- és úttengelyt nyerjük, mely a Ferencziek-tere környékén csekély szög alatt megtöri ugyan a Kossuth Lajos-utcza tengelyét, a régi városház és a belvárosi templom déli homlokzatai alatt mintegy 13 méternyi távolságban elhalad, Budán pedig a Rudasfürdő előtti park északi részébe torkollik!" ${ }^{39} \mathrm{E}$ javaslat még nem feltételezi a plébániatemplom lebontását, azonban a szabályozásban ennek ellenére javasolja a templom áthelyezését a régi városház terére.

A városszabályozási szituációk vázolják azt a helyzetet, amely nem csak a századvég Budapestjének szabályozására volt jellemző - a gondolkodásmód azokat a meghatározott elveket követi, amelyek divatosnak számítottak, azonban a szabályozásra felkért szakemberek csoportjai a helyi viszonyokra alakítás mellett gyakran ütköztették a véleményeket és a megoldásokat ${ }^{40}$. Az Eskü téri hídfö és környékének szabályozási tervét végül Lechner Lajos, Heuffel Adolf és Devecis Ferenc készítették el ${ }^{41}$.

\footnotetext{
${ }^{36}$ Stübben 1911. 108. Megjegyzés: az eredeti, német kiadás 1890-es, a hivatkozás az angol kiadást veszi alapul.

${ }^{37}$ Palóczi 1903. 81-83.

${ }^{38}$ Palóczi: Az eskütéri hid elhelyezése és a kapcsolatos városrészek szabályozása. Magyar Ipar 16 (1895. 03. 31.) 3. 74-81.

${ }^{39}$ Palóczi Antal: Az eskütéri hid elhelyezése és a kapcsolatos városrészek szabályozása. Magyar Ipar 16 (1895. 03. 31.) 3. 78 .

${ }^{40} \mathrm{~A}$ bemutatott és nagyvonalakban elemzett tervek mellett még meg kell említeni Nagy Dezső tervét, amely az Épitő Ipar hasábjain jelent meg 1894-ben: Budapest legújabb szabályozása. Épitö Ipar 18 (1894. 03. 07.) 10-896. 114.

${ }^{41} \mathrm{Az}$ Eskütéri hid környékének a székes főv. középitési bizottság által elfogadott szabályozási terve, 1903. Jelzet: FSZEK BT 220.
} 
A belvárosi plébániatemplomot megtartották eredeti helyén, viszont a lehetséges szcenárió - a templom eltolása - még sokáig téma maradt az építészek körében. Palóczi 1902-es felolvasásában összegezte azokat a követelményeket, amelyek mint „müvészeti és szépészeti igények” (Camillo Sitte hatása) a templom elhelyezésének kérdésében felmerültek. A templom elhelyezésére nem tartotta alkalmasnak az Eskü út és a Váci utca sarkán levő telket, mert a lejtős forgalmi téren csak mellékes szerep jutna a templomnak, ugyanis a tér „fömomentumát” a híd kapuzata adná. Véleménye szerint a templom kedvezőtlen párhuzamban állna egy bérházzal, ,a melylyel sem alakilag, sem eszmeileg meg nem egyeztethető" ${ }^{42}$. E probléma megoldására egy új

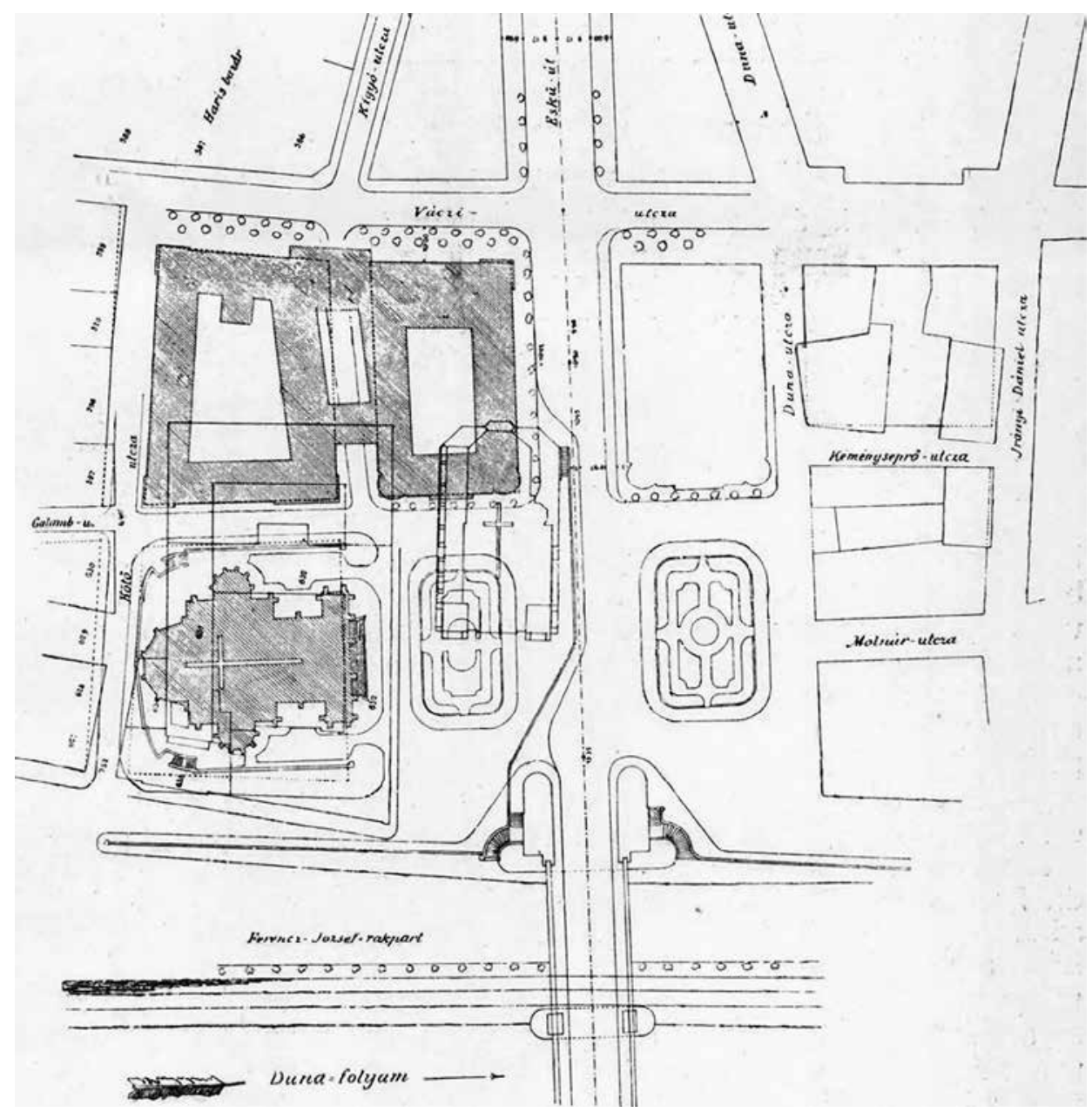

4. ábra. Az Eskü tér végleges terve - Heuffel Adolf 1896/1908. Forrás: Épitö Ipar 32 (1908. 10. 11.) 41.387

${ }^{42}$ MMÉEHÉ 21 (1902) 1-40. 149. 


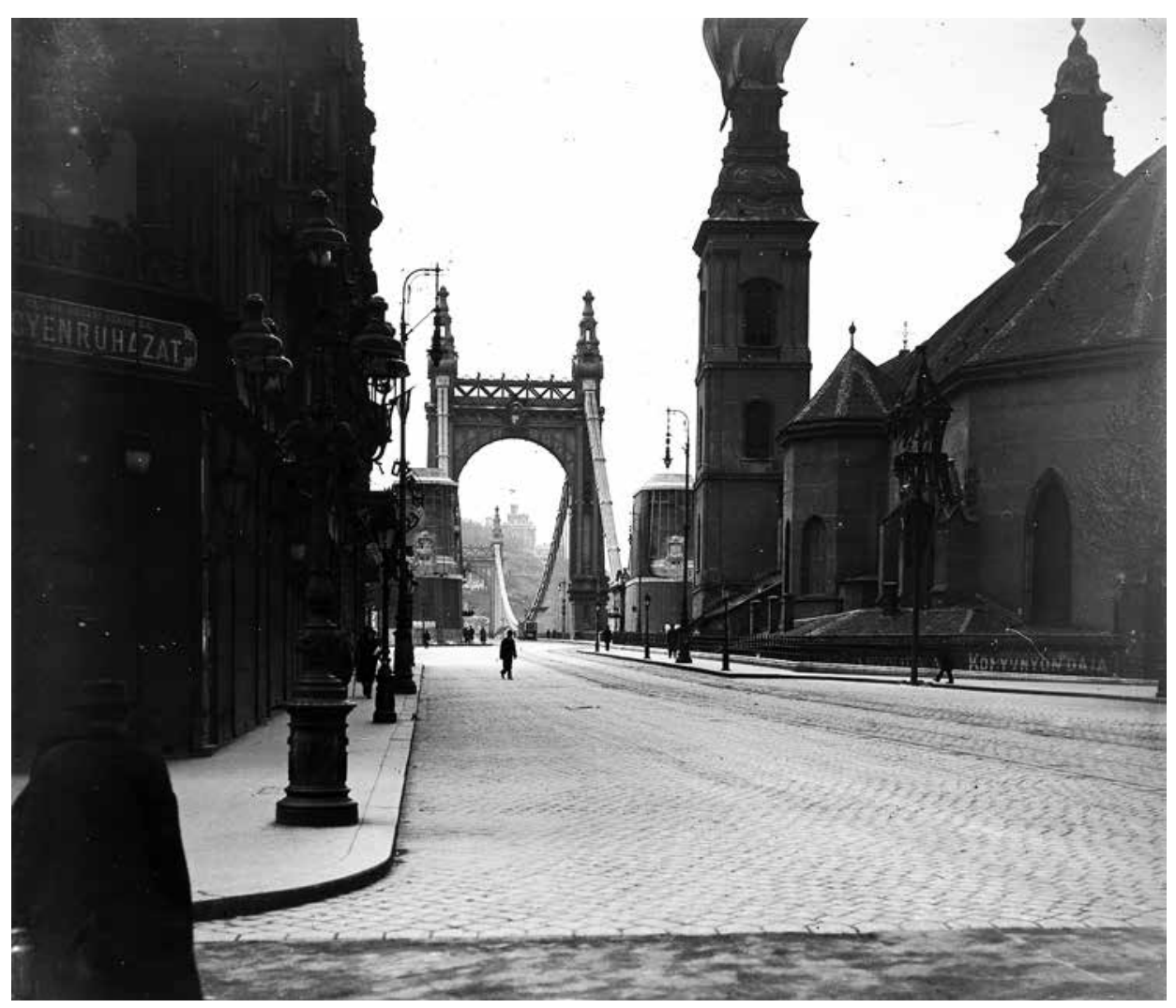

5. ábra. Eskü út a Váci utca sarkáról nézve, jobbra a Belvárosi templom. A felvétel 1919-ben készült. Forrás: Fortepan/adományozó: Schoch/képszám: 27910

tervet szerkeszett és mutatott be, amely a templomot a volt Városház térre helyezi, amely az apszisával a Kötő utca frontja felé néz a föhomlokzatát az Eskü út felé irányítva. „Elötte szép és a templom méreteihez arányos, szabályos tér lenne, mely jól védett gyülekező hely s a templom a Váci-utcából már messziről látható volna"43.

A változtatások okait nem hangsúlyozzák ki a korabeli iratok, azonban utalnak peres ügyekre a kisajátításokkal kapcsolatban, anyagi érdekekre (a terv megvalósításának költségei, amelyben benne foglaltatnak a kisajátításra és a terv fizikai megvalósítására vonatkozó költségek is), az érdekellentétekre (FKT, székesfőváros, egyház) s a tervjavaslatokra, amelyek egy adott pillanatban megfelelőnek tüntek, azonban ezt felülírták a fent említett okok. A tervek sokasága egyéni ambíciókat is mutat, hiszen a Magyar Mérnök- és Építész-Egylet tagjai, attól függetlenül, hogy az Fővárosi Közmunkák Tanácsán vagy a székesfőváros müszaki osztályán dolgoztak vagy sem,

${ }^{43}$ Uo. 
önszántukból vagy pályázati anyagként tervjavaslatokat készítettek - ez a tendencia más, korabeli szabályozásnál is megmutatkozik.

1908-ban az Épitő Ipar számol be a belváros szabályozásának utolsó felvonásáról: „Budapest belvárosának teljes szabályozása, mely az Eskü téri híd tervezésével kezdődött s melyet a székesföváros törvényhatósága 1896. évben állapított meg, éveken keresztül folyt tanácskozások és tervezgetések után most: tizenkét év múlva nyert befejezést, legalább a végleges tervben való megállapodást tekintve - azzal, hogy a már végrehajtás alatt levő eddigi belvárosi szabályozás utolsó részletét: a kegyesrendiek Városház téri telkének rendezését is elfogadta a székesföváros hatósága folyó hó 7-én tartott közgyülésében." ${ }^{44}$

A végleges tervet Heuffel Adolf, a székesföváros középítési igazgatója készítette még 1896-ban, de elfogadására 12 év múlva került 1908-ban (4. ábra). A véglegesnek mondott terv ellenére egy, a belvárosi templomot meghagyó hídfő kialakítása valósult meg (5. ábra).

\section{AZ ÚJ VÁROSHÁZA HELYE - TERVJAVASLATOK, AMELYEKET FELÜLÍRT A SZABÁLYOZÁS}

1898-ban az „eskütéri Dunahid pesti és budai feljáróinak kiképzése”45 nem csak a mai Erzsébet híd hídföinek területére volt hatással, a diskurzus kiterjedt a belvárosra és annak intézményeire is, így a szakrális (plébániatemplom) és szekuláris (vásárcsarnok, régi városháza) épületekre is. A híd építése, $\mathrm{s}$ föleg a pesti hídfő kihatott az új városháza ${ }^{46}$ tervezési mechanizmusára is, ugyanis a „Rózsa-tér és Sebestyénutczán át a hatvani-utcza torkolatáig" ${ }^{" 47}$ tartó új útvonal nyitására kötelez az 1893. évi XIV. törvénycikk.

Nem véletlen, hogy az új városháza helyének és formájának meghatározása az 1897/98-ban kiírt városrendezési és építészeti pályázat tárgya volt ${ }^{48}$, s egyik funkciójaként az akkor erösen különváló Pest és Buda egyesítésének reprezentációját határozták meg. A dunai hidakat tekintették az egyesült székesfőváros tényleges egyesítése gyakorlati eszközének, ezért az új városháza helyének kijelölése is kapcsolódik a hidakhoz, mégpedig a mai Erzsébet híd építéséhez. Bár Palóczi már 1892ben megtervezte a székházat, azonban helyének kijelölése egészen 1898-ig váratott magára. A Magyar Mérnök- és Építész-Egylet „Budapesti új városháza hovahelyezé-

${ }^{44}$ Épitö Ipar 32 (1908. 10. 11.) 41. 387-388.

${ }^{45}$ II. Az uj hidakkal kapcsolatos rendezés. Jegyzőkönyv. In: FKT jelentés (1898) 16.

${ }^{46} \mathrm{Az}$ új városháza terve nem valósult meg, azonban a városmorfológia hatásainak szempontjából fontos elemezni az esetleges szituációkat nemcsak a városháza, hanem az Erzsébet híd megvalósulási fázisainak figyelembevételével is.

${ }^{47}$ Idézve: 1893. évi XIV. törvénycikk a fö- és székvárosban két állami Duna-hid épitéséröl. Ma ez a Március 15. tér és a Kossuth Lajos utca vonala a Klotild palotával (Rózsa tér).

${ }^{48}$ Magyar Ipar 19 (1898) 925. 


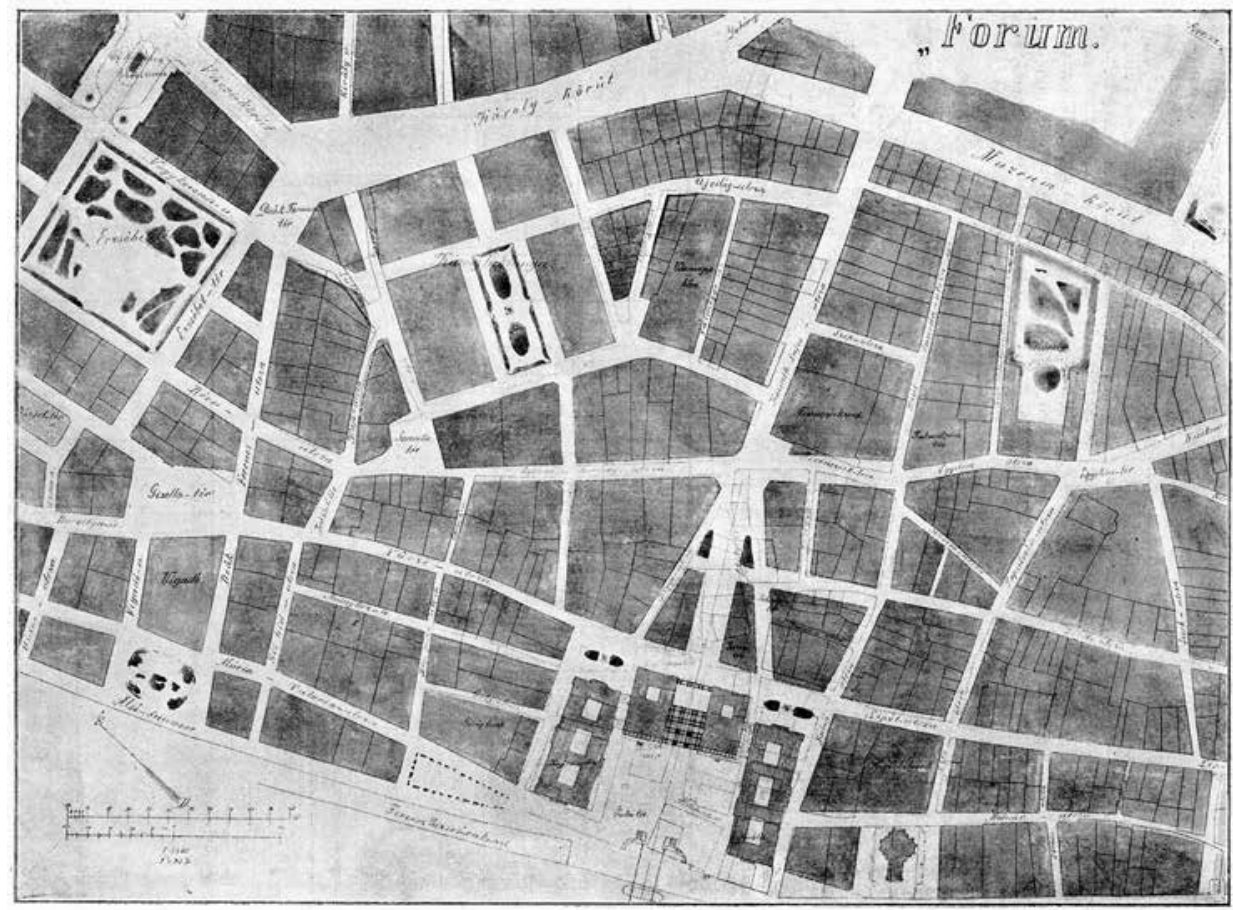

6. ábra. A budapesti új városház elhelyezése (Palóczi Antal, 1898), a Magyar Mérnök- és Építész-Egylet „Budapesti új városháza hovahelyezésének (1898)” pályázata, 2. díjas terv. Forrás: MMÉEHÉ 17 (1898) 16. 119

sének" pályázatán (1898) Palóczi pályázata, amelyen a városháza helyét a Duna partján jelölte ki, második díjat ${ }^{49}$ kapott (6. ábra).

A helyszín kiválasztása Sitte hatását mutatja, „megfelel az épület czentrális elhelyezési követelményének, szebb, impozánsabb, nagyszerübb környezetet számára a város belsejében seholsem találhatni, csak itt a Dunapartnak ez élesen előtörő domborulat tájékán, a honnan részből egy valóságos egységes főváros amugyis gyönyörü látképét ragyogóvá fogná tetézni és befejezni" ${ }^{50}$.

A székesföváros törvényhatósági bizottsága 1898. május 4-5-én tartott ülésének határozata szerint az ekkor még a 4. kerülethez (belváros) tartozó Károly laktanya telke és környéke szabályozásának és rendezésének céljából tervpályázatot hirdetett ${ }^{51}$. Palóczi újragondolt pályázatát kiemelten jónak ítélték (7. ábra).

Palóczi két terve a városháza elhelyezését tekintve nagyban különbözik egymástól, ugyanis a Duna-parti elhelyezést bírálta felül, s döntött a második pályázati ki-

${ }^{49}$ MMÉEHÉ 17 (1898) 119.

${ }^{50}$ Palóczi Antal: Az uj városházáról. Magyar Ipar 19 (1898. 02. 20.) 8. 135.

${ }^{51}$ Palóczi Antal: Budapest városházáról. Magyar Ipar 21 (1900. 05. 06.) 18. 548. 


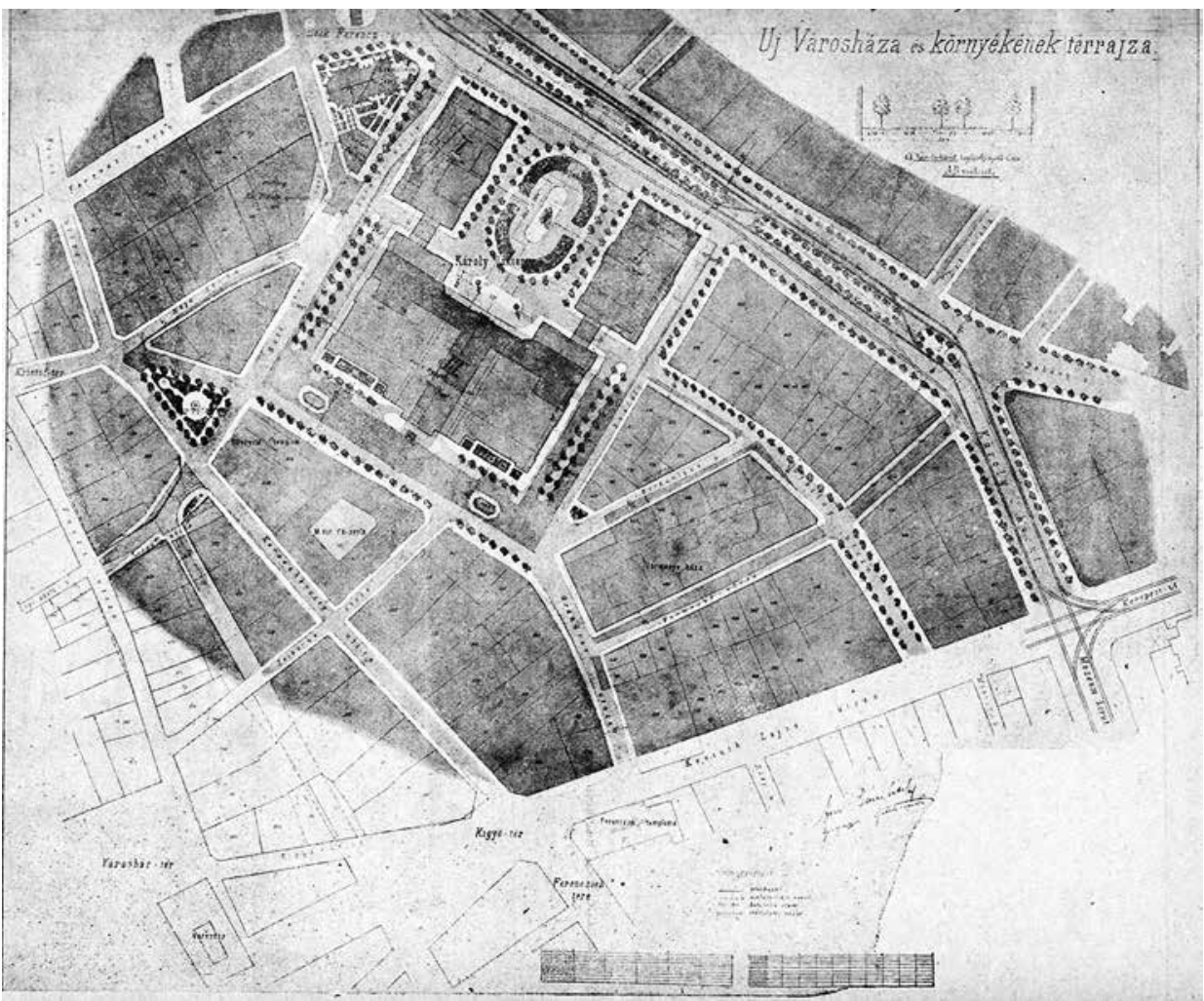

7. ábra. Az új városháza és környékének térrajza (Palóczi Antal, 1898). A székesfőváros törvényhatósági bizottsága, a Károly laktanya telke és környéke szabályozásának és rendezésének céljából kiírt tervpályázatának kiemelten jónak ítélt terve. Forrás: Magyar Ipar 21 (1900. 05. 20.) 20. 605

írásban szereplő Károly laktanya mellett. A korabeli bírálatok megoszlanak a helyszínválasztást illetően, azonban fontos momentumai a városszövet-változások hatásai szempontjából. A két helyszín közül a városépítő szakemberek a Duna-partot részesítették előnyben, s bár Palóczi végül a laktanya mellett tette le voksát, így ír 1900-ban: „Úgy látszik tehát, hogy le kell mondanunk nekünk épitö-szakembereknek arról a szép eszméről, hogy a helyett, hogy Budapest főváros legelső rangú épülete, városháza, a főváros legelőkelőbb, legfényesebb pontján: az eskü-téri hidfö előtt ékeskedjék, ott a bérkaszárnyák és áruházak kérkedő talmi pompájának kell díszelegni, mig uj városházunk a városnak egyik mindennapos, közönyös pontján kénytelen meghúzódni; szinte ellenezve a helyével azt, hogy Buda és Pest egységes Budapestté vált." ${ }^{52} \mathrm{~A}$ második tervnél a városház két különálló pavilonját a közbefoglalt nyílt parkokkal közvetlenül a Károly körút határvonalára állította, az emeletek

${ }^{52}$ I. m. 547. 
áthaladó folyosói összekötik a három részböl álló épületet, így annak minden helyisége szabad térre nyílik.

Az új városháza elhelyezésének kérdése, miután ideiglenesen kijelölték a központi városháza helyét (Károly laktanya), az Erzsébet út nyitása miatt újra a szabályozási kérdések középpontjába került. Az 1913 júniusában elfogadott szabályrendelet szerint a központi városháza nem marad meg jelenlegi helyén, ugyanis a tömb felszabadulásával a parcellázott területet értékesítik., ,[...] az uj városházát esetleg azon a tömbön építik fel, melyet a Károly-körut, Dob-utcza, Rombach-utcza és Király-utcza határol. E terv szerint az Erzsébet-ut a Karoly-körutbol kiindulva 25 meter szélességben nyittatnék meg és kapcsolatba hozatnék a Damjanich-utczával. [...] A terv a Rombach-utczát az uj városház kiszemelt telke mentén kiszélesíti 35 méterre." ${ }^{" 53}$ Azonban a döntést elnapolták, valamint 1914 elején a székesföváros közönsége a szabályozási tervet elejtette és határozatát egészen hatályon kívül helyezte.

1913. április 15-én írta ki a Magyar Építőművészek Szövetsége pályázatát a „Budapest új városházának elhelyezése és a nagy körútig terjedő városrész szabályozása" ${ }^{54}$ címen, amelynek díjazott pályamüvét Palóczi Antal készítette (8. ábra), ahol a városháza a Károly laktanya telkén van.

Palóczi terve a teljes városrész szabályozását $\mathrm{s}$ az ebből adódó léptékváltást irányozta elő. A városi tömbök kialakítását olyan új utak nyitásával érte el, mint a városnegyed tengelyében nyitandó Erzsébet út, amely felvezeti az új városháza épületkomplexumát. A szabályozás a Kossuth Lajos utca és a Rákóczi út bal oldalára is kiterjed (a Duna felől nézve), s ezzel szemben megfigyelhetők a Rákóczi út jobb oldalán elhelyezkedő városi tömbök, melyek dimenziói még a rendezés elötti összetettséget képviselik, amelyeket nem lazítanak a tömbökön átvágó utcák.

Az 1914-ben elfogadott szabályozási terv szerint, amelyet a székesfővárosi tanács III. ügyosztálya készített, az Erzsébetvároson keresztül, a központi városházához vezetendő 25 méter széles út a Rottenbiller és Damjanich utcák találkozásánál kezdődik. „A Rombach-utcza és Károly-körut között az ut nagyobb méretü térszerü kiképzésbe jut és a központi városháza telkének homlokzatára közel merőlegesen kapcsolódik a Károly-körut forgalmába" ${ }^{55}$. A városháza ügye nyitott maradt, habár az FKT javaslatot tett egy újabb építészeti pályázat kiírására is.

A bemutatott városmorfológiai változások hivatottak vázolni azokat a lehetőségeket, amelyek hatása a főváros városszerkezeti és városszöveti mintázatában megjelent. Az Erzsébet híd pesti hídföjének és az új városháznak a kérdésére adott változatos megoldások és válaszok azonban hasonló városszöveti mintát mutatnak, amelynek domináló eleme a hídfö és közvetlen környezetének kiképzése, s a közvetlen környezetében levő szekuláris és szakrális intézmények. Az új városháza helyéül kijelölt Károly laktanya (Invalidusok háza) az Osztrák-Magyar Monarchia időszakában a tervek megvalósítása nélkül is a városháza szerepét töltötte be. Az a

\footnotetext{
${ }^{53}$ II. Szabályozás. In: FKT jelentés $(1913,1914,1915)$ 21-23.

${ }^{54}$ Épitö Ipar 37 (1913. 01. 26.) 4. 43.

${ }^{55}$ II. Szabályozás. In: FKT jelentés $(1913,1914,1915)$ 21-23.
} 
döntés, miszerint a belvárosi plébániatemplom érintetlenül marad, kihatott a ma is álló Erzsébet híd pesti hídföjének kiképzésére. A belvárosi templomnak és környékének 1909-es szabályozási terve lényegében nem változott az 1896-ban megállapított tervhez viszonyítva, eltérés csak abban volt, hogy a főváros új tervezete a templomot a mai helyén meghagyja, a Duna-part felé eső területet pedig - mely az 1906-os szabályozási tervben az új templom számára volt kijelölve - a főváros javára értékesítendő építési telekké alakítja. Az így kialakított tér megoldása nem a kor kívánalmainak megfelelő, azonban a fennálló különleges helyzet miatt kompromisszumokat kötöttek a várostervezők: a tényleges térfalakat felváltotta a Duna és a híd felhajtója által lezárt tér.

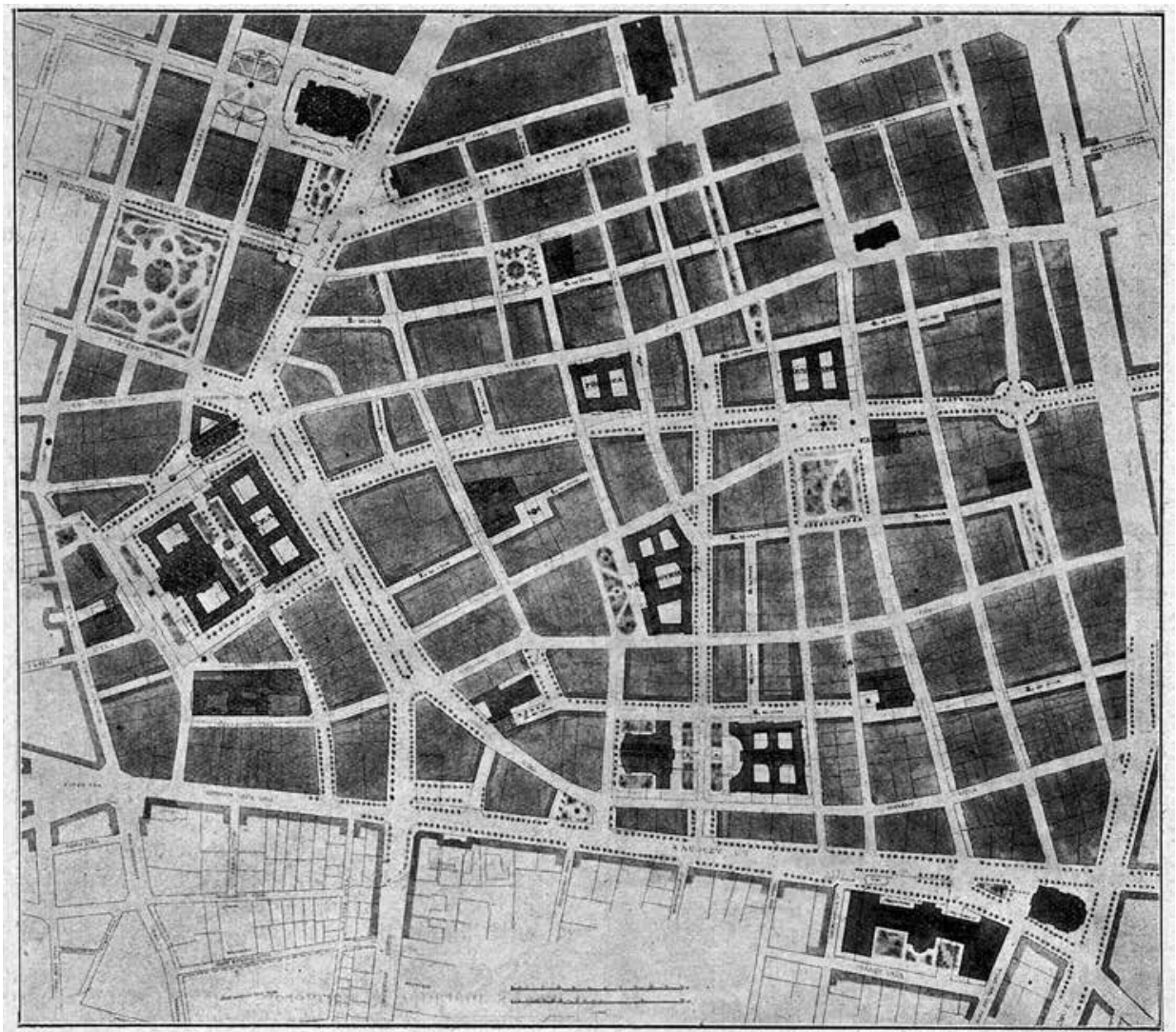

8. ábra. Palóczi Antal díjazott pályaterve a budapesti városháza elhelyezésére (1913). Magyar Építőmúvészek Szövetsége pályázata a „Budapest új városházának elhelyezése és a nagy körútig terjedő városrész szabályozása”. Forrás: Épitö Ipar 37 (1913. 06. 22.) 25. 273 


\section{A BUDAI KÖRÚT ATTILA KÖRÚTI SZAKASZA - LÉPTÉKVÁLTÁS ÉS TELJES SZERKEZETI ÁTALAKULÁS (MEGVALÓSÍTATLAN ELKÉPZELÉS)}

Az Attila körút és környezetének szabályozása, a telkek kisajátítások által való rendezésének elindítása egy városrész urbanizációjának ígéretét vonta maga után, ugyanis, mint az FKT jelentésében írja: „Hasonlókép nem téveszthető szem elől a nagy áldozattal épített Erzsébet-hid sem, mely csak azután fogja rendeltetését teljes mértékben betölthetni, ha az Attila-körút föforgalmi jellegének megfelelöen szabályozva és telkei városi módra kiépitve lesznek"

A budai körút Attila körúti szakaszának szabályozása, a Tabán rendezésének előfutára drasztikus beavatkozást, a városrész struktúrájának teljes átalakulását, városmorfológiájának újragondolását jelentette volna, amennyiben megvalósulnak a tervek. A tervjavaslatokon és a szabályozási elképzelésekben a léptékváltás nemcsak a városi tömbök szintjén figyelhető meg a megvalósítandó új körút / sugárút vonalán, hanem a kapcsolódó utcaszerkezet szintjén is.

Az egyesített fóváros budai részének fejlesztésében nagy szerepet szántak a budai belső körútnak, melynek 1908-ban, az Attila körút szabályozásáról szóló törvény hatálybalépésének évében (1908. évi XLVIII. tc.) a vonalát képezte a Margit körút, Krisztina körút, Attila körút, az Erzsébet híd jobb parti feljárói és a Gellért rakparti út. E körút szabályozásának és kiépítésének müvelete szerves összefüggésben állt a pesti oldal belső körútjaival (a Lipót, Váczi, Károly, Múzeum és Vámház körúttal ${ }^{57}$ ). A Margit híd és a Ferencz József híd (ma Szabadság híd) által teljes körré fejlesztett közlekedési vonal a belöle különböző irányban kiágazó sugárutakkal a város forgalmi viszonyainak szolgálatában áll. „A budai sugárutaknak, illetőleg a budai forgalmi úthálózatnak csak az eskütéri hid képezheti kiindulási pontját. A város térképén ennek kell dominálni, s ennélfogva e központtal való organikus kapcsolat nem utólagos hozzátoldással oldandó meg"- írta Mudrony Soma 1893-ban (Mudrony 1893. 19).

A budai körutat eredetileg úgy tervezték, hogy az a Vérmező útról az Attila utcába fordulva folytatódjon, ennek megvalósítása érdekében az utat kiszélesítették volna, azonban a Közmunkatanács 1885-ös jelentésében ${ }^{58}$ írta, hogy a budai körút más irányt vett, a kiszélesítést az út egy részén, a Mikó utcától északra elvetették. 1899-ig a budai belső körutat szakaszonként fokozatosan rendezték és szabályozták a Közmunkatanács és a székesfőváros közös költségén, kivéve a Krisztina körút azon részét, amely a Mikó utcától a Maros utcáig terjed ${ }^{59}$. Buda ezen területén nemcsak a terepviszonyok, hanem a vízfolyások is nehezítették a városrendezést. Ennek a szakasznak a szabályozásánál irányadónak vette az FKT, „hogy az ördögárok vonala mindenütt közterület alá kerüljön"60. Az FKT 1906. évi jelentésében számot

\footnotetext{
${ }^{56}$ III. Útépités. In: FKT jelentés (1906) 27.

${ }^{57}$ Ma ezek a körutak: Szent István körút, Bajcsy-Zsilinszky út és Károly, Múzeum és Vámház körút.

${ }^{58}$ I. Szabályozás. In: FKT jelentés (1885).

${ }^{59}$ FKT jelentés (1899) 78.

${ }^{60}$ I. Szabályozás. In: FKT jelentés (1901) 7.
} 
ad arról, hogy már az 1880-as években egyezményre léptek a székesfővárossal, hogy a jobb parti belső körút vonalát közös erővel szabaddá tegyék és rendezzék - így a körút legnagyobb részének szabályozását elvégezték, azonban az Attila körút szabályozási vonalnak megfelelö, 10 ölre való kiszélesítése elmaradt. 1906-ban újra napirendre került az Attila körút szabályozása: „mert a mai állapot, tekintettel a közúti vaspálya kettős vágányra történt kifejlesztésére, a társaskocsi-közlekedésre s a különben is nagy kocsi- és föleg teherforgalomra, biztonsági szempontból is türhetetlenül veszélyes, különösen azon pontokon, hol az út szükületei a forgalom rendes lebonyolitását lehetetlenné teszik" ${ }^{61}$.

A főváros az 1906. december 13-i, 270662. sz. a. határozata alapján a kisajátítási költségek ismerete nélkül nem foglalt állást, azonban egy vegyes bizottság megalakításához hozzájárult, amely az Attila-körúttal kapcsolatos müveletekkel foglalkozik. Javasolják a Szarvas utca 6 ölre való kiszélesítését, az Árok utca (a mai Krisztina körút egy szakasza) elsőrangú burkolattal való ellátását (mivel a körút végleges szélességét 10 ölben határozták meg, ezért felmerült az Árok utca 6 ölröl 10 ölre való kiszélesítése). A tárgyalások folytatásaként Palóczi Antal mutatta be tervét az FKT és a székesfőváros bizottságának 1907. május 10-én ${ }^{62}$.

Az Országos Iparegyesület 1907 májusában tartott ülésén újra felvetődött a kérdés: „Hogyan kellett volna és hogyan kell még megépíteni az Attila-körutat?”63 A fővárost még mindig az elszigetelt tervek mentén fejlesztették egységes városfejlesztő program nélkül, amely pontosan kijelölné az irányokat. Így a pesti oldal elszigetelt projektjeihez (Eskü tér, Uj-épület, Erzsébet sugár-út, pályaudvarok rendezése, hidak) csatlakoztak a budai oldal elképzelései. Az Attila körút kiszélesítését már 1892-ben határozatban fogadta el a Közmunkatanács, azonban a főváros középítési bizottsága ezt a javaslatot elvetette. Az Erzsébet híd (Eskü téri híd) azonban újra sürgetővé tette az útvonal kijelölését és szabályozását. A budai körút csak folyamatában vizsgálható, így elindulva az Erzsébet híd budai hídföjének környezetétől egészen a mai Krisztina körút végéig. Az 1892-es javaslat szerint az Erzsébet híd hídföjétől egy 30 méter széles, tekintélyes útvonal indul a korabeli „városépítésnek megfelelö felfogással, mely ott nem csak szélességi méretezést, hanem müvészetet is kiván a vezetésben és kialkotásban" ${ }^{\text {". E }}$ Ez az útvonal a Rác fürdő és a Rác templom között vezetne, enyhe görbülettel az akkori Árok utcán haladva tovább, és a királyi palota előtt impozáns térré bővülne ki. A Közmunkatanács 1907-ben határozatában elfogadott néhány, a szélesebb sugárút hiányát enyhíteni kívánó olyan szabályozást, mint az Árok utca kiszélesítése. Az FKT 1907. évi hivatalos jelentésében a budai belső körutat jelentő utak szélességéröl ad leírást, s hozzáteszi, hogy „az Attila-utcza Szent János-tér és Szarvas-tér közötti szakaszát csak az Árok-utczára szolgáló átlós telkek feláldozásával lehetett volna 10 ölnél szélesebbre venni” ${ }^{65}$. Azonban figyelem-

\footnotetext{
${ }^{61}$ III. Útépités. In: FKT jelentés (1906) 26.

${ }^{62}$ III. Útépités. In: FKT jelentés (1907) 52.

${ }^{63}$ Palóczi Antal: A budai körut. Magyar Ipar 28 (1907. 05. 12.) 19. 464-469.

${ }^{64}$ I. m. 466.

${ }^{65}$ I. Szabályozás. In: FKT jelentés (1907) 25.
} 


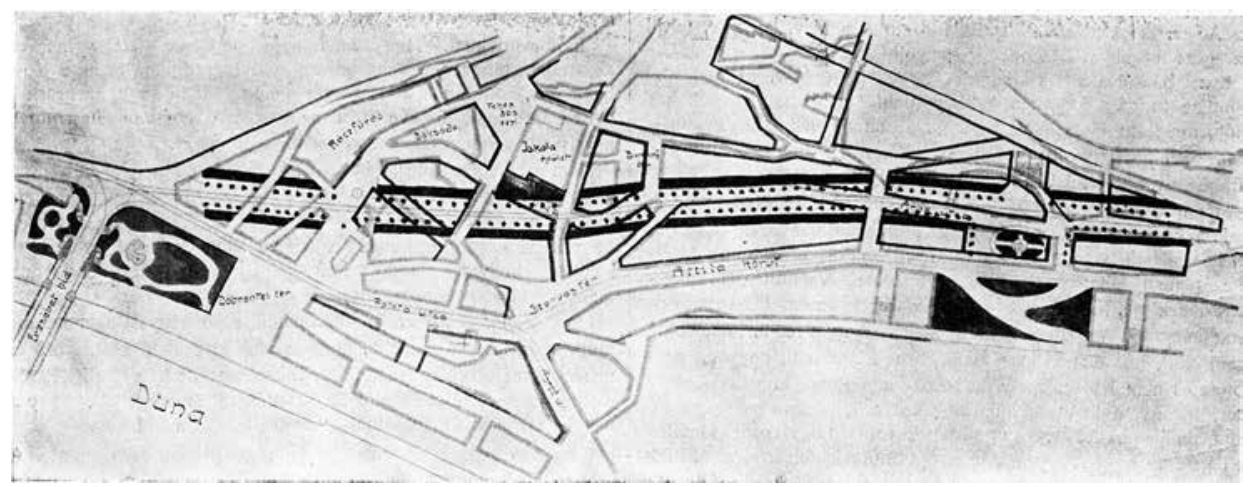

9. ábra. Uj „Boulevard” a jobb parti városban (Palóczy Antal, 1907). Az esztétikai, funkcionális és költségvetési érvekkel alátámasztott terv szerint az Attila utca és Árok utca kiszélesítése kedvezötlenebb megoldás, mint egy új „boulevard” létesítése, amely az Ördögárkot is egész folyásában érintetlenül hagyja. Forrás: MMÉEHÉ 26 (1907) 17. 185

be kellett venni azt, hogy a Palota utca kiszélesítése nem lehetséges az ott elhelyezkedő templom homlokzati vonalának hátrébb tolása nélkül, így a „budai körút” nevezett utcákon keresztül vezető kiszélesítésének folytatását 10 ölre redukálták. „,[...] A budai körút befejező részének tekintendő a Döbrentey-tér és a Gellért-rakpart, mely utóbbi szélessége 12 ölben lett megállapítva." ${ }^{66}$

Palóczi Antal új javaslata figyelembe veszi az eddig elfogadott rendelkezéseket, és azokkal az új épületekkel is számol az útvonal mentén, amelyek 1892 és 1907 között épültek: így az út legkisebb szélessége 26 méter vagy 14 öl (közúti vasúttal ellátott út minimális szélessége), s a kor várostervezési elveinek megfelelően: „Egyenesen vezetni a föútvonalat a völgyterületen át nem lehet - nem is kívánatos, minthogy az iv alakú - enyhe hajlitásban vezetett ut esztétikai értéke sokkal magasabban áll az egyenes úté fölött' ${ }^{\prime 67}$. Nemcsak esztétikai és funkcionális érvekkel támasztja alá az általa javasolt út építését, hanem a kisajátítási adatokkal és a megvalósítás költségével is - ezek szerint az Attila utca és Árok utca kiszélesítése kedvezőtlenebb megoldás, mint egy új „,boulevard” létesítése, amely az Ördögárkot is egész folyásában érintetlenül hagyja (9. ábra).

Az 1908. évi XLVIII. tc. 1. §. legitimálja a budai Attila út szélesítését és szabályozását, ugyanis a munkálatok elvégzésére pénzalapot hoztak létre. Az FKT 1908. évi jelentésében szerepel, hogy a körút és környezetének szabályozására vonatkozó tárgyalásokat elnapolták ,azon eszmék s tervezetek sorsának végleges eldöltéig, melyek egyfelöl az Attila-körút kiszélesitese, másfelöl es különösen az Attila-körúttal párhuzamosan haladó Árok-utcza vonalában egy új körút létesítése iránt felmerültek" ${ }^{68}$. Erre vonatkozóan Palóczi Antal építész tanár és Devecis Ferencz székesfővá-

${ }^{66}$ Uo.

${ }^{67}$ Palóczi Antal: A budai körut. Magyar Ipar 28 (1907. 05. 12.) 19. 468.

${ }^{68}$ III. Útépités. In: FKT jelentés (1908) 10. 


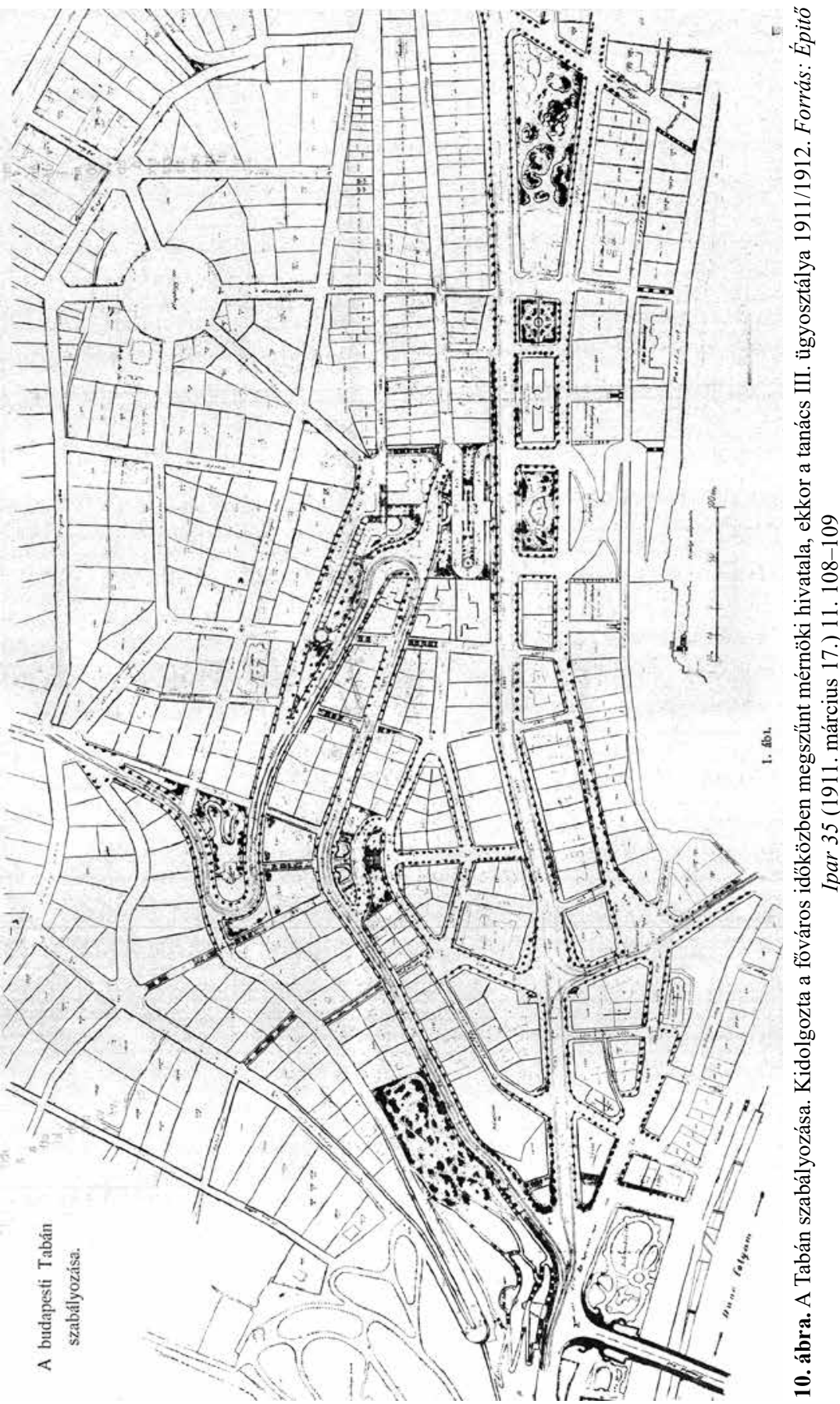


rosi müszaki tanácsos dolgoztak ki terveket ${ }^{69}$, mindkét tervező tervjavaslata szerint az új körút a Döbrentei téri hídlejáróból indulna ki, majd az Árok utca vonalában haladva jutna el a Szt. János térre ${ }^{70}$. Palóczi a körút szélességére 26 métert, míg Devecis 30 métert javasol. A székesföváros, miután foglalkozott a javaslatokkal, a 30 méter széles út nyitása mellett döntött, s ehhez az FKT hozzájárulását kérte, akik az ügyet a város müszaki osztályának számításaival együtt az FKT müszaki bizottságához utalták, hogy azután ennek javaslata alapján határozzanak.

A következő évben a körút kérdésében nem jutottak megegyezésre, a városszabályozást kiterjesztették a Tabán területére, amelynek kapcsán több alternatív tervet dolgoztak ki a székesfőváros és a Fővárosi Közmunkák Tanácsa müszaki bizottsága, valamint a Magyar Mérnök- és Építész-Egylet képviselői (közöttük Palóczi Antal) is.

1910-ben, az FKT jelentése szerint az Attila körút szabályozására szánt pénzalap (1908: XLVIII. tc.) átcsoportosítását indítványozták, és felhasználását a Tabán rendezésére. Még ugyanebben az évben, a már elindult kisajátításokkal párhuzamosan megindult a Tabán részletes szabályozási és rendezési tervének kidolgozása a székesfőváros mérnöki hivatalában. A városrész újjáépítésének gondolata 1909-ben merült fel az Attila körút tárgyalásai során, $\mathrm{s}$ a Tabán végleges szabályozási és rendezési tervét 1911-ben állapították meg: „Az Árok-utcza vonalában létesítendő s a rendezési művelet súlypontját képező körút $30 \mathrm{~m}$ széles lesz. Ez a körút a Döbrentei-téri hídfeljáróból indul ki; a Kereszt-utczáig egyenes vonalban halad és itt a polgári iskola előtt térszerúen kibővül. [...]"71 Az Attila körút a terveben 8 öl szélességgel szerepel, kivéve a Szarvas tér és a Döbrentei tér közötti szakaszt, amely az érvényben levő szabályozási terv szerint 10 öl szélességben megmarad (10. ábra).

Palóczi Antal álláspontja szerint ,[...] e hivatalos tervben nemcsak hogy bizonyos merevség mutatkozik a vonalzásban, de azzal, hogy egyenlőtlen házfrontok egymással szembesítvék, hogy a Rácfürdő elött lévő tért nyomban követi a fehérsastéri iskola ferdén álló homlokzatával alakított térkibővítés, az útvonal egységes nagy hatása felaprózódik, monumentális szép hatása gyengül. [...] a homorú beállítás ad szép hatást, minden domborúságot okvetetlenül kerülni kell nemcsak a házhomlokzatokban, de az utca szintjében is." "ᄁ2

Megoldási javaslatában ${ }^{73}$, amely kiegészíti a főváros tervét, a Rác fürdő előtti teret követő és a fehérsasréti iskola ferdén álló homlokzatával kialakított térbővítést megszünteti, hogy az útvonal homorú vezetését ne szakítsa meg a teresedés. A Szarvas tér alakját is rendezi, amelyet a szabályozási terv az oda szélesen betorkolló utca által szabálytalanná tesz. A további módosítások ,abban nyilatkoznak meg, hogy a vonalvezetést kelet felé kellene némileg eltolni, amivel az folyékonyabbá lesz, szög-

${ }^{69}$ A 30 m szélességben tervezett budai új körút - a mérnöki hivatal tervével összevonva (Palóczy Antal, 1908). Jelzet: FSzEK BT 392.

${ }^{70} \mathrm{Ma}$ a Krisztina és az Árpád körút találkozásában.

${ }^{71}$ I. Szabályozás. In: FKT jelentés (1912) 5-6.

${ }^{72}$ Épitö Ipar 35 (1911. 03 17.) 11. 107.

${ }^{73}$ Épitö Ipar 35 (1911. 03. 17.) 11. 108-109. 
letessége kissé enyhül, kiemelődik továbbá monumentális hatása azzal, hogy a határoló telekblokkok egymással szemben egyenlő és megegyező hosszú szakaszokra osztódnak." ${ }^{4}$

A Tabán szabályozásának kérdése még évtizedekig nyitott maradt, $\mathrm{s}$ a világháború után a század húszas éveiben tértek vissza a feladathoz. A szabályozások megvalósításával teljesen átépítették volna, amely a kibontakozó modern előszele is lehetett volna akár: „Régi városok átépítésekor tervszerüleg és egyöntetűen kell eljárni; ha a régi házak nem tarthatók meg, azokat egyszerre, vagy utcák, vagy háztömbönkínt kell lebontani, és az így nyert és szabályozott területet újból beépíteni. Igy járt el a múlt évtizedben Prága városa, midőn a zsidónegyedet átépítette és így jár majd el Budapest is, midőn Palóczi Antal javaslatára a Tabán helyén tabula rasa-t alkot." 75

\section{A VÁROSMORFOLÓGIAI VÁLTOZÁSOK HATÁSA - KÖVETKEZTETÉSEK}

Budapest várostervezési, szabályozási rétegei nem értelmezhetők csupán a városmorfológiai elemzések, az aktuális és városrész-specifikus szabályozások által. Az 1872 és 1896 (1894), valamint 1896 (1894) és 1914 között lejátszódó városfejlesztési folyamatok megfelelő értelmezéséhez, valamint ahhoz, hogy rámutassunk a tervezési anomáliákra, amelyek megakadályozták az egységes városszerkezet és harmonikus városszövet-kombinációk kialakítását, ismernünk kell a városfejlődés rétegeit, valamint a döntések mögött álló elveket és gyakorlati feladatokat. A városmorfológiai változások hatásánál figyelembe kell venni az 1914-es, a városrendezés szempontjából egyik jelentős szabályozás, valamint a városfejlesztés eseményeinek, Bárczy István polgármester modern Nagy-Budapest víziójának (Harrer-Bárczy 1908) megtorpanását, amit az első világháború kitörése idézett elő.

Budapest alaki változásaira, ha nem is feltétlenül tudatosan, de hatottak a korszak városteoretikusainak leírt gondolatai, amelyek minden város tervezési szabályzatában valamilyen módon helyet kaptak abból az okból kifolyólag, hogy a hirtelen növekedésnek induló városok a fejlődésük egy pontján ugyanazokkal a problémákkal találkoztak. Az irányadó elvek, illetve a városszabályozás megoldandó feladatai között szerepel a közegészségügy, amelynek megoldását a megfelelő lakhatásban és a város zöldterületi rendszerének kiterjesztésében látták: Podmaniczky Frigyes, az 1870-ben megalakult Közmunkatanács alelnöke is javasolta a parkok (népkertek) létesítését a meglévő parkok oly módon való átalakításával és újak létesítésével, hogy azok a közegészségügyi kívánalmaknak megfelelve egy-egy zöldövezetet hozzanak létre a székesfővárosban. Nemcsak az újonnan beépítendő városrészeken szorgalmazta a zöldterületek (közparkok, allék) létesítését, hanem a város belső, már beépí-

\footnotetext{
${ }^{74}$ Épitö Ipar 35 (1911. 03. 17.) 11. 108.

${ }^{75}$ Épitö Ipar 35 (1911. 03. 19.) 12. 114.
} 
tett területeinek sétányain és terein (a későbbi Stübben- és Sitte-féle platz) példaként az angol gyakorlatot felhozva. A közlekedés problémájának megoldásában a Josef Stübben-féle, addig is alkalmazott, viszont csak a század végén leírt elvek találtak teljes befogadásra. Stübben szerint a sugárirányú utcák kialakítása a várostervezés leghatékonyabb eszköze, amelyek egy, a közlekedés és közegészség szempontjából megfelelő rendszer kialakítását teszik lehetővé; a város központi pontja körül a különböző hierarchiájú körutak koncentrálódnak, s a sugárirányú utak és a körutak merőlegesen metszik egymást, így a fö utcák között trapéz, megközelítőleg téglalap vagy (különösen az átlós utcák mentén) háromszög alakú teleksorozatokat, illetve negyedeket, épülettömböket alkotnak. Sitte munkájának is egyik kardinális kérdése volt a városon belüli megfelelő kommunikáció kialakítása, amit a festői kilátást is lehetővé tevő, funkcionális, azonban nem kizárólag egyenes utak alkotnak. Gondolatai inkább a város mủvészeti elveken való kialakítására hatottak, amelyek figyelembe veszik a terület morfológiáját és ügyelnek a múlttal való folytonosság kialakítására és a térképzésre. Palóczi mellett többek között Forbáth Imre, Kotál Henrik és Warga László is a Sitte-vonalat követte, s ez megmutatkozik a terveik úthálózati és tömegkompozíciós megoldásaiban.

A bemutatott négy esettanulmány mellett még ugyanennyi tanulmányozása, valamint a tanulmányban csak említett szabályzatok, döntési mechanizmusok megvizsgálása alapján alkotható kép a várost érintő várostervezési feladatokról. Az esettanulmányok kiválasztásának szempontjai követték a kor (1867-1918) fejlesztési dinamikáját. A városegyesítés és 1896 (1894) között egy egységes, határozott városfejlesztés zajlott le - a megvalósult elképzelések, mint a körutak, sugárutak szakmai és társadalmi elfogadásra találtak. Városmorfológiai szempontból környezetük is jól definiálható és rendszerezhetö. A léptékváltás a városszerkezet és a városi tömbök szintjén megvalósult, s a köztes területek is megfelelő minőséggel töltődtek ki. Az 1894-ig kiépített városszövetet mint a kor fejlődési tendenciái értelmezésének és megértésének alapját a millennium évtizedének és az azt követő időszakának városszabályozási és várostervezési döntéseivel és szándékaival együtt vizsgáltuk - a kiválasztás egyik pontja. Azok a területek állnak az elemzés fókuszában, ahol a fejlesztés valamilyen társadalmi és szakmai diskurzust generált, több ötlet felvetését, pályázatok kírását, amelyek végül kialakítására is hatottak. Az esettanulmányok területei Budapest változatos városmorfológiai térképét is (részben) megrajzolták Budától Pestig.

A levonható következtetések:

- Az egyesített Budapest várostervezési időszaka két részre osztható: 1870 (az egyesítés ratifikálása) és 1896 között (ebben az 1894-es építésügyi szabályrendelet és a millennium is közrejátszik); 1896-1918 (1920). 1870-1896: egységes, centralizált beruházások; kiemelt beruházások - reprezentáció; jelentős szerkezeti átalakítás - elszigetelt, azonban kapcsolódó projektek (sugár- és körút); elkülönített, megbolygathatatlan pénzalap; egyedi szabályozás (részletes és minimális módosításokat megengedő); fö szerkezeti elemek, jellemző úthálózat: ortogonális / raszter, sugár- és körutak hálózata. 1896-1918: egyedi, a meglévő városszövetet rendező beruházások 
a belvárosban; egységes szemlélet (egységes városszabályozási terv gondolata), ebbe illeszkedő rendezés, a reprezentáció helyett funkcionális városszabályozás; szabályozás a korabeli rendezési elvek figyelembevételével; pénzalap: átrendeződés, prioritásváltás, egyének szerepe (kisajátítás helyett kollaboráció); szabályrendeletek folyamatos változása - igazítás az igényekhez (gyakran a tervjavaslat megelőzte a szabályozási rendeletet); az utak és a városi tömbök szerkezete idomul a terület morfológiájához, lehetőleg kerülik a központi (orientációs) elem nélküli hosszú, egyenes utak kialakítását.

- Várostervezés az új elvek mentén (az 1880-as évek végétől): közegészségügy, lakhatás, forgalmi kérdések, esztétika és a megfelelő szabályozás (az elvek kialakítására a Deutscher Verein für öffentliche Gesundheitspflege kongresszusának várossal foglalkozó tézisei, Reinhard Baumeister, Camillo Sitte és Josef Stübben voltak a legnagyobb hatással).

- Budapest városmorfológiai változásainak hátterében nemcsak a szabályozási rendeletek egy-egy megvalósított intézkedése áll, hanem azok a szakemberek és alkotók is, akik aktívan részt vettek a városszabályozási diskurzusban ${ }^{76}$.

- A várostervezési háromszög: székesfőváros, FKT és a szakegyletek (MMÉE, Országos Iparegyesület) mérnökei. A végső döntést egy tervjavaslatról a székesföváros közönségének elfogadása után a belügyminisztérium hozta.

- A várostervezési háromszög egymásrautaltsága nemcsak a döntésekben nyilvánult meg (az FKT javasolt és a főváros fogadta el, vagy fordítva, a végső döntés a szakmáé és a székesföváros közönségéé, majd jogerőre a belügyminisztériumban lép), hanem a tervek kidolgozásában: az ötletek és szakemberek cserélődtek (nincs teljes elszigeteltség az intézmények között a tervek kidolgozását tekintve).

- Ha egy tervjavaslattal kapcsolatos szabályozás érintett egy kiemelt beruházást, akkor arról a beruházásról külön döntöttek (pl. a mai Belügyminisztérium épülete és a mai József Attila utca egységes szabályozása).

- A léptékváltás nem csak az egész város területére vonatkozó építésügyi szabályrendeletek változó szabályozásának eredménye. Az utcaszélesítés az épületmagasság / utcaszélesség meghatározott arányai miatt is magasabb épületek építését tette lehetővé.

- Kisajátítások: a szabályozások kivitelezését késleltették, de nem gátolták azok az esetek (épületek), amelyek tulajdonosai nem müködtek együtt (a későbbiekben jogi útra terelték, s a döntés után befejezték a munkát).

- Prioritások: 1896 után épületegyüttesek és kiterjedtebb városszövetek szabályozását nem kezelték kiemelten, egyes épületek építését igen. A prioritások felülírása, a pénzalapok átrendezése (Attila körút - Tabán), a gazdasági szempontok szerinti tervezés és szabályozás kerül elötérbe.

- A korabeli tematikus lapok nagy szerepet játszottak a tervek, szabályozások, elvek, pályázatok stb. naprakész bemutatásában. A szakmai kritikáknak is adtak he-

\footnotetext{
${ }^{76}$ A szabályzatok, rendezési és építési javaslatok kidolgozásában az illetékes Közmunka és Közlekedésügyi Minisztérium (1889-től), a Kereskedelmi Minisztérium, a Fővárosi Közmunkák Tanácsa és meghívásos alapon a Magyar Mérnök- és Építész-Egylet képviselői vettek részt.
} 
lyet, amelyek megalapozottságát bizonyítja, hogy hatással voltak a későbbi döntéshozatalra, $\mathrm{s}$ a tervjavaslatok egyes részeit átemelték a városszabályozási tervekbe is.

A szakmai kritika a városszabályozási tervek és szabályozási rendeletek (építési szabályzatok) közötti átfedések hiányára is kitért, bár az írott dokumentumhoz tartoztak térképek, amelyek pontosan meghatározták a fóváros területének övezeteit (például: Budapest övezeti beosztása, 1914. Jelzet: HU.BFL.XV.16.e.251.51b), azonban nem rendelkeztek olyan iránymutatással, amely pontosan meghatározta volna a város fejlődési irányát, csak kijelölte a lehetséges tematikus területeket. Az egész városra vonatkozó városszabályozási és városbővítési tervek, mint Pesten a Hild-féle terv 1805-ben vagy az 1871-ben kiírt pályázat, amely nemcsak az egységes Budapest, hanem a világvárossá válás ideáját ${ }^{77}$ is meg kívánta teremteni, csak évtizedekkel később váltak Budapest valóságává.

\section{FORRÁSOK ÉS IRODALOM}

FKT jelentés

FKT jelentés

FKT jelentés (1885)

FKT jelentés (1889, 1890, 1891)

FKT jelentés $(1892,1893,1894)$

FKT jelentés (1895)

FKT jelentés (1898)

FKT jelentés (1899)

FKT jelentés (1901)
A Fövárosi Közmunkák Tanácsa hivatalos jelentései 18701944. https://library.hungaricana.hu/hu/collection/fszek_ kozmunkaktanacsa/ (Utolsó megtekintés: 2019. 05. 06.) (1870, 1871) FKT hivatalos jelentése 1870. és 1871. évi müködéséröl. Pesti Könyvnyomda Részvény Vállalat, Budapest 1872.

A Fövárosi Közmunkák Tanácsának hivatalos jelentése 1885. évi müködéséröl. Nyomtatott Heisler J.-nál, Budapest 1886.

A Fövárosi Közmunkák Tanácsának hivatalos jelentése 1889. 1890. és 1891. évi müködéséröl. Nyom. Heisler J. Kö- és Könyvnyomdájában, Budapest 1892.

A Fövárosi Közmunkák Tanácsának hivatalos jelentése 1892. 1893. és 1894. évi müködéséröl. Nyomtatott Heisler J. Kö- és Könyvnyomdája, Budapest 1895.

A Fövárosi Közmunkák Tanácsának hivatalos jelentése 1895. évi müködéséröl. Heisler J. Kö- és Könyvnyomdája, Budapest 1896.

A Fövárosi Közmunkák Tanácsának hivatalos jelentése 1898. évi müködéséröl. Heisler J. Kö- és Könyvnyomdája, Budapest 1899.

A Fövárosi Közmunkák Tanácsának hivatalos jelentése 1899. évi müködéséröl. Nyomtatott Heisler J. Kö- és Könyvnyomdájában, Budapest 1900.

A Fővárosi Közmunkák Tanácsának hivatalos jelentése 1901. évi müködéséről. Heisler J. Kö- és Könyvnyomdája, Budapest 1902.

\footnotetext{
${ }^{77}$ „Azon czélból, hogy oly általános beosztási és rendezési terv nyeressék, melynek alapján Buda és Pest városok egységes fővárossá egyesittessenek, hogy azután mint országos főváros, mint a király és kormány székhelye, mint góczpontja az ország értelmi tényezőinek, egyrészt megfelelő jellegét és keretét nyerhesse, másrészt mint az ipar, kereskedelem és forgalom középpontja, ezek által és ezen haladási tényezőknek nyújtandó kedvezmények és könnyítések által világvárossá emeltessék!” Magyar Ipar 12 (1891. 11. 30.) 5.
} 
FKT jelentés (1906)

FKT jelentés (1907)

FKT jelentés (1908)

FKT jelentés (1912)

FKT jelentés (1913, 1914, 1915)

ÉSZ 1914

Harrer-Bárczy 1908

Moravánszky 1997

Moravčíková-Lovra-Pastoreková 2017 Moravčíková, Henrieta - Lovra Éva - Pastoreková, Laura:

MRT

Mudrony 1893

Palóczi 1903

Palóczy 1892

Pásztor 1909

Stübben 1890

Stübben 1907 Red or Blue? The Start of Modern Planning in Bratislava.

Architektúra \& Urbanizmus 51 (2017) 1-2. 30-43.

Fövárosi Közmunkák Tanácsának hivatalos jelentése 1906. évi müködéséröl. Heisler J. Kö- és Könyvnyomdája, Budapest 1907.

A Fövárosi Közmunkák Tanácsának hivatalos jelentése 1907. évi müködéséröl. Nyomtatott Heisler és Kózol Kö- és Könyvnyomdájában, Budapest 1908.

A Fövárosi Közmunkák Tanácsának hivatalos jelentése 1908. évi müködéséről. Nyomtatott Heisler és Kózol Kö- és Könyvnyomdájában, Budapest 1909.

A Fövárosi Közmunkák Tanácsának hivatalos jelentése 1912. évi müködéséröl. Nyomtatott Heisler és Kózol Kö- és Könyvnyomdájában, Budapest 1913.

Fövárosi Közmunkák Tanácsának hivatalos jelentése 1913. 1914. és 1915. évi müködéséröl. Nyomtatott Heisler és Kózol Kö- és Könyvnyomda Müintézetében, Budapest 1916.

Fővárosi Közmunkák Tanácsa: Építésügyi Szabályzat Budapest Székesfóváros területére. Hornyánszky Viktor cs. és kir. könyvnyomdája, Budapest 1914. OSZK TM 973

Harrer Ferenc - Bárczy István: A peremvárosok Budapesthez csatolásáról (részletek, 1908). In: Források Budapest múltjából II. 1873-1919. Budapest Föváros Levéltára forráskiadványai 2. Szerk.: Ságvári Ágnes. Budapest Főváros Levéltára, Budapest 1971. 73-78.

Moravánszky Ákos: Versengö látomások: Esztétikai újítás és társadalmi program az Osztrák-Magyar Monarchia épitészetében 1867-1918. Vince Kiadó, Budapest 1997.

Magyarországi Rendeletek Tára 1867-1945. https:/library. hungaricana.hu/en/collection/ogyk_rendeletek_tara/ (Utolsó megtekintés: 2019. 03. 02.)

Mudrony Soma: Budapest jövöje. Országos Iparegyesület, Budapest 1893.

Palóczi Antal: A városok rendezése: Budapest viszonyainak egybevételével. Magyar Mérnök- és Építész-Egylet, Budapest 1903.

Palóczy Antal: Budapest föváros alaki rendezéséröl: különös tekintettel a Belváros szabályozására. Neumayer Ny., Budapest 1892.

Pásztor Mihály: A régi Pest. Müvészet 8 (1909) 6. 382-391. http://www.mke.hu/lyka/08/382-391-pest.htm (Utolsó megtekintés: 2019. 05. 27.)

Stübben, Josef: Der Städtebau. A. Kröner, Lipcse 1890. https://archive.org/details/derstdtebau00stgoog (Utolsó megtekintés: 2019. 02. 17.)

Stübben, Josef: City Building. Fordította: A. Albrecht 1907ben. Újra kiadva Julia Koschinsky és Emily Talen által. Eredeti kiadás: Cambridge 1911. 


\title{
FOLYÓIRATOK
}

\author{
Épitö Ipar \\ Magyar Ipar \\ Magyar Mérnök- és Épitesz-Egylet Heti Értesitője (MMÉEHÉ) \\ Magyar Mérnök- és Épitész-Egylet Közlönye (MMÉEK) \\ Müvészet
}

\section{LEVÉLTÁRI ANYAG}

\author{
FSzEK Fővárosi Szabó Ervin Könyvtár \\ OSzK Országos Széchényi Könyvtár
}

\section{THE MOST IMPORTANT URBAN MORPHOLOGICAL CHANGES OF BUDAPEST (1867-1918) THROUGH REGULATIONS AND CASE STUDIES}

\begin{abstract}
Summary
The urban morphological changes of Budapest are not only the result of the implementation of certain regulatory acts but also of those professionals who have actively participated in the urban regulation discourse. The urban planning and regulatory layers of Budapest cannot be interpreted solely by urban morphological analyses, current and neighbourhood-specific regulations. It is necessary to understand layers of urban development, principles and practical tasks behind the decisions in order to properly interpret the urban development processes between 1872 and 1896 (1894) and 1896 (1894) and 1914. The study summarizes the planning and regulatory characteristics of the capital's post-merger period, with particular reference to the turn of the century. The presented case studies focus on one aspect of regulation and planning, along with a description of the processes. The evaluation of the case study areas in downtown Pest and in the Buda side partially covers the review of regulations, urban plans, tender, written and drawn documents related to the area; urban morphology analyses; the matching and assignment of contemporary design theory principles and the review of significant regulations in the field.
\end{abstract}

Keywords: Budapest, urban morphology, regulations, 1867-1918, urban planning

Open Access nyilatkozat: A cikk a Creative Commons Attribution 4.0 International License (https://creativecommons.org/licenses/by/4.0) feltételei szerint publikált Open Access közlemény, melynek szellemében a cikk bármilyen médiumban szabadon felhasználható, megosztható és újraközölhető, feltéve, hogy az eredeti szerző és a közlés helye, illetve a CC License linkje és az esetlegesen végrehajtott módosítások feltüntetésre kerülnek. (SID_1)

Beérkezett: 2019. május 27. Elfogadva: 2019. június 26.

Online First megjelenése: 2019. október 11. 